\title{
EFEITO DOS TEORES DE URÉIA E DO FARELO DE SOJA SOBRE A DIGESTIBILIDADE E BALANCO DE NITROGÊNIO EM VACAS LEITEIRAS ALIMENTADAS COM CANA-DE-ACUÚCAR
}

\author{
PAULO FARANO STACCHINI \\ Engenheiro Agrônomo
}

Orientador: Prof. Dr. Wilson Roberto Soares Mattos

\begin{abstract}
Dissertação apresentada à Escola Superior de Agricultura "Luiz de Queiroz", Universidade de São Paulo, para obtençào do título de Mestre em Agronomia, Área de Concentração: Ciência Animal e Pastagens.
\end{abstract}

PIRA CICA BA

Estado de São Paulo - Brasil

Dezembro - 1998 
Dados Internacionais de Catalogação na Publicação (CIP) DIVISÃo DE BIBLIOTECA E DOCUMENTAÇÃO - Campus "Luiz de Queiroz"/USP

Stacchini, Paulo Farano

Efeito dos teores de uréia e do farelo de soja sobre a digestibilidade e balanço de nitrogênio em vacas leiteiras alimentadas com cana-de-açúcar / Paulo Farano Stacchini. - - Piracicaba, 1998.

$67 \mathrm{p}$.

Dissertação (mestrado) - Escola Superior de Agricultura Luiz de Queiroz, 1998. Bibliografia.

1. Alimentação animal 2. Balanço de nitrogênio 3. Cana-de-açúcar 4. Digestibilidade 5. Farelo de soja 6. Uréia 7. Vaca Holandesa 8. Vaca leiteira 1. Título. 
Aos meus pais Aldo e Rosa Maria pelo amor, respeito e compreensão que sempre recebi e, principalmente, pelos valores transmitidos durante a minha formação.

Aos meus irmãos Renata, Fernando, Marcelo e Aldo pela amizade e por compreenderem minha ausência durante o programa de mestrado.

A minha esposa flávia pela paciência nos periodos de coleta e, principalmente, pelo seu amor, dedicação e apoio ao longo desta jornada. 


\section{AGRADECIMENTOS}

Ao Prof. Dr. Wilson R. S. Mattos pela experiência, dedicação e paciência na orientação e, principalmente, pela amizade construida durante o mestrado.

Às colegas Maria Claudia A. Sucupira e Soraia V. Matarazzo pela amizade, paciência e enorme auxilio em todas as etapas deste trabalho.

Ao Prof. Dr José M. C. Simas pelo grande auxilio durante toda realização desse projeto, pela amizade e, sobretudo, pelo exemplo de conduta pessoal e profissional.

Ao Prof. Dr. Alexandre V. Pires pela obtenção dos animais, realização das cirurgias. sugestões e apoio na condução dessa pesquisa.

Ao Prof. Dr. Evaristo Marzabal Neves pelo incentivo constante e apoio desde a época de Iniciação Científica até a elaboração da Dissertação.

Ao amigo Carlos C. Alves, técnico do Laboratório de Bromatologia da ESALQ-USP pela amizade, paciência e dedicação para ensinar e auxiliar na realização das análises bromatológicas.

Aos colegas Mário P. Menezes Jr. e Maria Teresa Guidi pela amizade, sugestões e auxilio na realização do experimento e análises laboratoriais.

À Escola Superior de Agricultura "Luiz de Queiroz" - ESALQ da Universidade de São Paulo pela minha formação na Graduação e pela oportunidade de realizar o mestrado.

Ao CNPq pela concessão da bolsa de Pós-graduação.

À FAPESP pelo auxilio financeiro ao projeto, viabilizando sua realização. 


\section{SUMÁRIO}

1 INTRODUÇÃO

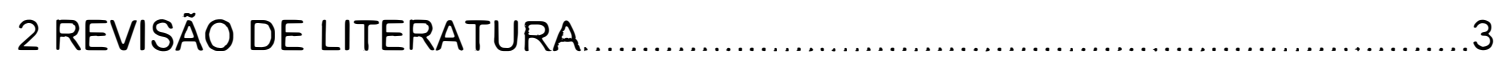

2.1 Vantagens da utilização da cana-de-açúcar .............................................

2.2 Limitações nutricionais da cana-de-açúcar ...........................................6

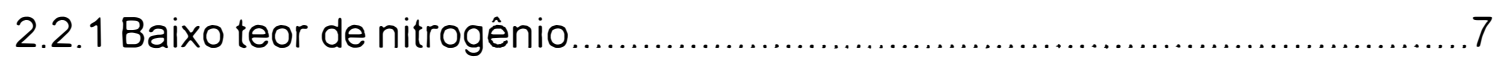

2.2.2 Suprimento de nutrientes para o pós rúmen ......................................

2.2.3 Digestibilidade da fração fibrosa ...................................................... 12

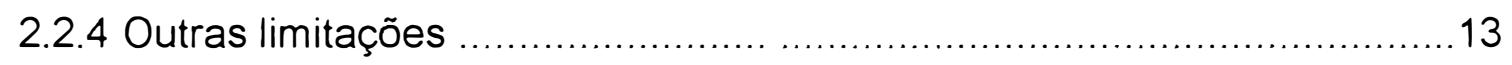

2.3 Suplementação de dietas com cana-de-açúcar .....................................14

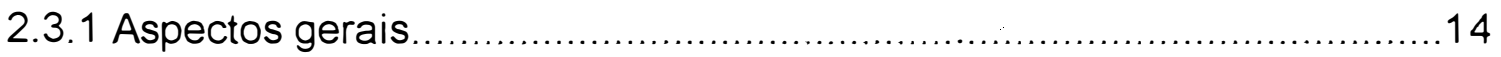

2.3.2 Suplementação com uréia em dietas com cana-de-açúcar...................15

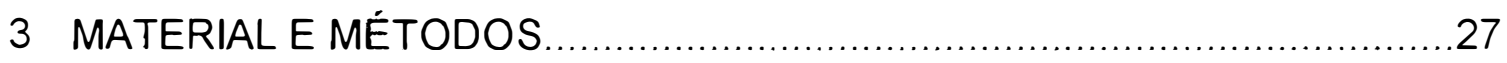

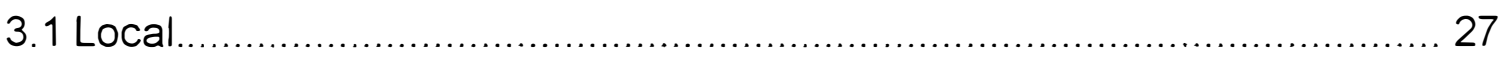

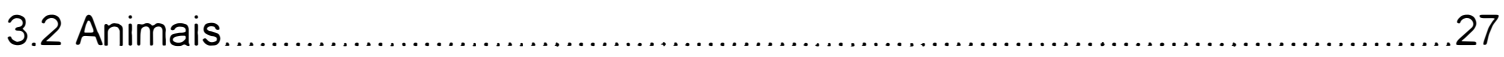

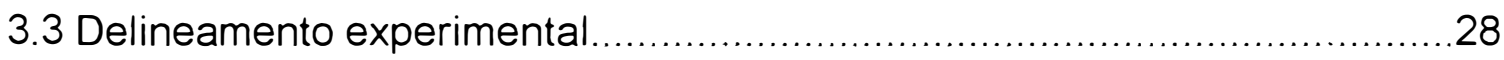

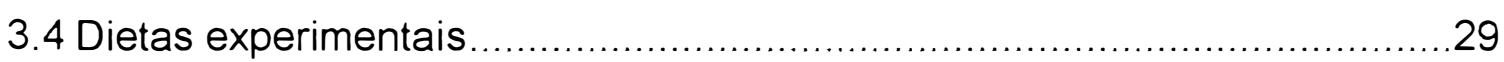

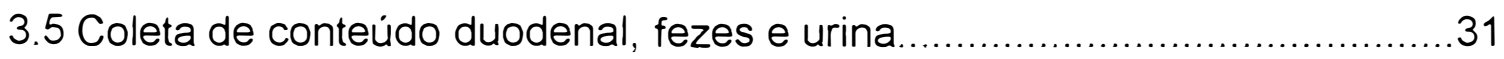

3.6 Processamento e análise das amostras................................................32

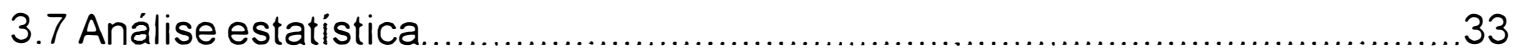

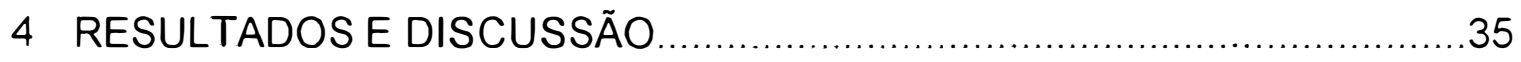

4.1 Graus Brix e composição química da cana-de-açúcar ..............................35

4.2 Análise bromatológica das dietas experimentais.................................38

4.3 Consumo e digestibilidade aparente no trato total da matéria seca ..........39

4.4 Consumo e digestibilidade aparente no trato total das diversas frações

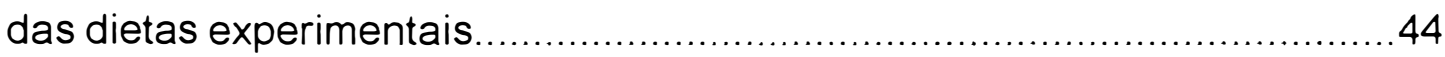

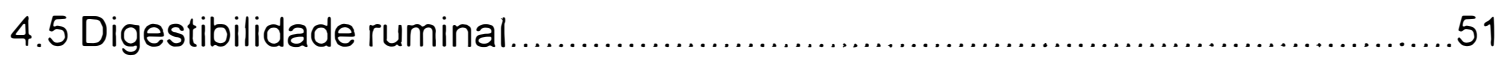

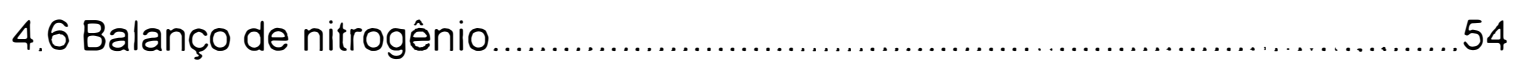


5 CONCLUSÕES

REFERÊNCIAS BIBLIOGRÁFICAS 60 


\section{LISTA DE TABELAS}

1. Efeito do teor de uréia sobre a digestibilidade aparente da matéria seca no trato total, em bovinos alimentados com dietas à base de cana-de-açúcar.

2. Quadrado latino $4 \times 4$ balanceado para efeito residual constituido por quatro períodos, quatro vacas e quatro tratamentos.

3. Análise de variância para ensaio de digestibilidade e balanço de nitrogênio.

4. Composição química da cana-de-açúcar e do farelo de soja

5. Teores de uréia calculados para os períodos experimentais de acordo com os graus Brix do suco da cana.

6. Composição bromatológica das dietas experimentais

7. Consumo e digestibilidade aparente da matéria seca no trato total.

8. Consumo e digestibilidade aparente das demais frações das dietas no trato total.

9. Concentração e consumo de energia digestivel

10. Consumo de nitrogênio, excreção total de nitrogênio, excreção urinária de nitrogênio, excreção fecal de nitrogênio, balanço de nitrogênio e nitrogênio retido. 


\section{LISTA DE FIGURAS}

1. Alterações na composição química da cana-de-açúcar em função da idade da planta.

2. Precipitação total média $(\mathrm{mm})$ por decêndio em Piracicaba em 1997.

3. Consumo de nitrogênio, nitrogênio excretado, balanço de nitrogênio, nitrogênio excretado na urina e nitrogênio excretado nas fezes. 


\title{
EFEITO DOS TEORES DE URÉIA E DO FARELO DE SOJA SOBRE A DIGESTIBILIDADE E BALANÇO DE NITROGÊNIO EM VACAS LEITEIRAS ALIMENTADAS COM CANA-DE-AÇÚCAR
}

\author{
Autor: Paulo Farano Stacchini \\ Orientador: Prof. Dr. Wilson Roberto Soares Mattos
}

\section{RESUMO}

Quatro vacas holandesas, não lactantes, pesando cerca de $600 \mathrm{~kg}$, foram utilizadas num delineamento quadrado latino $4 \times 4$ para se avaliar 0 efeito dos teores de uréia e do farelo de soja em dietas à base de cana-deaçúcar sobre a digestibilidade e balanço de nitrogênio. As dietas experimentais eram constituídas de cana-de-açúcar como volumoso exclusivo, suplementada com farelo de soja no tratamento $A$ e 1,0; 1,5 e 2,0\% de uréia sobre o peso da cana fresca nos tratamentos $\mathrm{B}, \mathrm{C}$ e $\mathrm{D}$, respectivamente. $\mathrm{O}$ consumo de matéria seca (MS), matéria orgânica (MO), fibra em detergente neutro (FDN), fibra em detergente ácido (FDA), energia bruta (EB) e energia digestivel foi superior para o tratamento $A$ em relação aos tratamentos $B, C$ e $D$. Verificou-se maior digestibilidade aparente no trato total da MS, MO, EB e maior retenção de nitrogênio para o tratamento $A$ em relação ao tratamento $B$. No entanto, quando comparado ao tratamento $C$, o tratamento $A$ não apresentou diferenças na digestibilidade aparente no trato total da MS, MO, FDN, FDA, EB e retenção de nitrogênio $(N)$. Isso sugere que teores entre 14 a $16 \%$ de proteina bruta devem ser necessários para maximizar a digestibilidade dos nutrientes e a utilização do nitrogênio em dietas à base de cana suplementadas, exclusivamente, com uréia. O uso de uréia na concentração de 2,0\% não foi vantajoso por apresentar maior perda de nitrogênio via urina, sem trazer benefícios na digestibilidade e ingestão de MS e demais frações da dieta. quando comparado com as concentrações de 1,0 e 1,5\%. 


\title{
EFFECT OF THE UREA LEVELS AND SOYBEAN MEAL ON THE DIGESTIBILITY AND NITROGEN BALANCE IN DAIRY COWS FED SUGAR CANE BASED DIETS
}

\author{
Author: Paulo Farano Stacchini \\ Adviser: Prof. Wilson Roberto Soares Mattos
}

\section{SUMMARY}

Four dry Holstein cows, weighing about $600 \mathrm{~kg}$ were used in a $4 \times 4$ latin square to evaluate the effect of urea levels and soybean meal in sugar cane based diets in nutrient digestibility and nitrogen balance. The experimental diets were based on sugar cane as exclusive roughage plus soybean meal in treatment $A$, and 1,$0 ; 1,5$ and $2,0 \%$ urea on fresh sugar cane basis in treatments $B, C$ and $D$, respectively. Dry matter intake (DM), organic matter (OM), neutral detergent fiber (NDF), acid detergent fiber (ADF), gross energy (GE) and digestible energy were higher in treatment $A$ than all the other treatments. The total tract digestibility of $\mathrm{DM}, \mathrm{OM}, \mathrm{GE}$ and nitrogen retention were higher in treatment $A$ than in treatment $B$. There were no differences between treatment $A$ and $C$ in regard to $\mathrm{DM}, \mathrm{OM}, \mathrm{NDF}, \mathrm{ADF}, \mathrm{GE}$ digestibility and nitrogen retention. This suggests that the levels of crude protein between 14 and $16 \%$ may be required to improve nutrient digestibilities and nitrogen utilization in sugar cane based diets supplemented with urea as the sole nitrogen source. The use of $2,0 \%$ urea didn't show any beneficial effect and yet showed a higher loss of urine nitrogen. 


\section{INTRODUÇÃO}

Dentre os fatores responsáveis pela baixa produção de leite no Brasil, destaca-se a presença de um posicionamento pouco profissional nos estabelecimentos rurais produtores de leite, caracterizado pela ausência de um planejamento para alocação e utilização racional dos recursos produtivos das propriedades. O reflexo de tal filosofia manifesta-se, em boa parte, na forma extrativista de utilização do solo e das plantas forrageiras nele cultivadas, gerando, via de regra, baixa produção de alimentos. Com isso, ignora-se a principal vantagem da utilização de ruminantes nos trópicos, que é a possibilidade de se explorar o elevado potencial de produção de matéria seca (MS) por unidade de área das espécies forrageiras tropicais. Pesa ainda, distorcendo o sistema de produção, a ocorrência de produções sazonais, como conseqüência da maior oferta de alimentos durante a época de predominância das chuvas (outubro a março) e grande escassez de alimentos durante 0 período da seca (abril a setembro).

Dentre as várias alternativas que podem ser usadas para suplementação de volumosos para os bovinos nos períodos de escassez de forragem, a canade-açúcar ocupa posição invejável. Cultura de elevada produção de MS e energia por hectare (ha), a cana-de-açúcar apresenta máxima produção exatamente nos periodos de seca. Essas características aliadas à pequena redução do seu valor nutritivo com o avanço no tempo, dispensam a necessidade de técnicas de conservação, tornando a cana-de-açúcar uma 
opção barata (tecnologia de baixo custo) e extremamente interessante para alimentação de ruminantes no período de escassez de forragens.

A utilização da cana-de-açúcar como recurso forrageiro para ruminantes é dependente, no entanto, de correções nas dietas para superar uma série de limitações do ponto de vista nutricional, principalmente em relação ao baixo teor de proteina bruta (PB), baixa ingestão de matéria seca e reduzida digestibilidade da fibra. As pesquisas realizadas no sentido de identificar e superar tais limitações apontam para a necessidade de suplementação com: fontes de proteína degradável ou nitrogênio não protéico (NNP) para atender às exigências de $\mathrm{N}$ dos microrganismos ruminais, amido e proteína de baixa degradabilidade ruminal para atender às exigências de glucose e aminoácidos dos animais.

A utilização de NNP, especificamente a uréia, tem sido recomendada para corrigir o baixo teor de proteína bruta das dietas à base de cana-deaçúcar. Tal combinação permite associar uma fonte de nitrogênio prontamente disponivel no rúmen ao seu elevado conteúdo de carboidratos não estruturais.

As recomendações sobre a quantidade de uréia a ser suplementada em dietas à base de cana-de-açúcar fundamentam-se, principalmente, em pesquisas com bovinos de corte em crescimento, nas quais, principalmente, parâmetros de desempenho foram analisados. No entanto, são escassas as informações sobre os efeitos de diferentes teores de uréia sobre o metabolismo de vacas leiteiras consumindo dietas à base de cana-de-açúcar.

A presente pesquisa tem como objetivo avaliar, através de ensaios de digestibilidade e balanço de nitrogênio, a utilização da uréia (em diferentes concentrações) e do farelo de soja como fontes de proteína para vacas leiteiras alimentadas com dietas à base de cana-de-açúcar. 


\section{REVISÃO DE LITERATURA}

\subsection{Vantagens da utilização da cana-de-açúcar}

Embora há muito difundida no Brasil, principalmente para fins industriais, a cultura da cana-de-açúcar vem ganhando importância como alimento volumoso na pecuária de leite e corte, apesar de não se contar com dados estatísticos oficiais e recentes que permitam estimar com precisão sua quantidade utilizada com essa finalidade. Entre as razões que explicam esse fato, as vantagens do cultivo da cana-de-açúcar têm sido mencionada por vários autores.

Pate (1981) destacou que a cana-de-açúcar apresenta elevado rendimento de MS, aumento na digestibilidade com a aproximação da maturidade e manutenção do valor nutritivo por vários meses após a maturidade. Segundo este autor, tais características são particularmente valiosas nas regiões que experimentam problemas na produção de alimentos mais convencionais, como grãos e silagem de sorgo ou milho. Segundo Peixoto (1986) a facilidade da cultura, a coincidência da safra com o período de escassez de forragem, a manutenção das qualidades nutritivas por períodos prolongados de tempo e a aceitação pelo gado constituem razões suficientes para explicar a demanda crescente de cana como alimento volumosos para os ruminantes. Boin \& Tedeschi (1993) relataram várias vantagens na utilização da cana-de-açúcar como recurso forrageiro, como alto potencial de produção de MS e energia por hectare (ha), disponibilidade com maior valor energético 
no período seco do ano, pequenos riscos de produção, alta disponibilidade de variedades e facilidade de vendas de excedentes ou aquisição de cana junto às usinas de açúcar e álcool.

A elevada produção de MS e energia por unidade de área tem sido destacada por vários autores como uma das principais vantagens da cana-deaçúcar. Segundo Preston \& Willis (1974), a cana-de-açúcar alcança facilmente produções da ordem de 10 a 20 toneladas de nutrientes digestiveis totais (NDT) por hectare, superando as culturas de milho, sorgo e mandioca, que mal chegam a atingir três toneladas de NDT/ha.

Considerando-se que o rendimento médio da cultura da cana-de-açúcar no Estado de São Paulo situa-se em torno de 80 toneladas de colmos por hectare e que as pontas representam de 20 a $30 \%$ do peso total da cana, obtém-se rendimento médio da cana-de-açúcar integral fresca da ordem de 100 a 110 t/ha (Boin, 1985). Levando-se em conta que a cana integral apresenta cerca de $28 \%$ de MS, obtém-se um rendimento médio de 28 a 30 toneladas de MS/ha/ano. Isso faz da cana, uma das gramíneas tropicais de maior potencial de produção de matéria seca e energia por unidade de área com um único corte no ano.

Outra vantagem da cana-de-açúcar como alimento volumoso é a manutenção de seu valor nutritivo durante periodos prolongados de tempo. Banda \& Valdez (1976) analisaram o valor nutritivo da cana-de-açúcar cortada com 8 ou 16 meses após o plantio. A cana imatura (cortada aos 8 meses) apresentou menores teores de extrativos nitrogenados e maiores de $\mathrm{PB}$, extrato etéreo e componentes da fração fibrosa em relação à cana-de-açúcar mais madura (cortada aos 16 meses). O resultado para graus Brix (concentração de sólidos solúveis) no suco foi de $14,5^{\circ}$ e $16,3^{\circ}$ enquanto a digestibilidade in vitro da MS foi de 50,7 e $70,5 \%$ para a cana imatura e 
madura, respectivamente. Segundo os autores, o aumento no teor de conteúdo celular que ocorre com o avanço na maturidade é uma função do acúmulo de sacarose e esta exerce um efeito de diluição dos componentes da parede celular.

Pate (1977) estudou o valor nutritivo da cana-de-açúcar durante 336 dias de crescimento e verificou que os teores de PB, fibra insolúvel em detergente neutro (FDN) e fibra insolúvel em detergente ácido (FDA) decresciam e os teores de extrativo não nitrogenado aumentavam, à medida que as plantas tornavam-se mais maduras. Ele constatou que, apesar de ocorrer decréscimo no teor de PB e na digestibilidade da FDN com o avanço na idade das plantas, o aumento das frações de conteúdo celular e extrativo não nitrogenado, permitiu a ocorrência de aumento na digestibilidade da matéria orgânica ( $\mathrm{MO}$ ) de 55,5 a $60,6 \%$ da primeira para última amostragem (Figura 1).

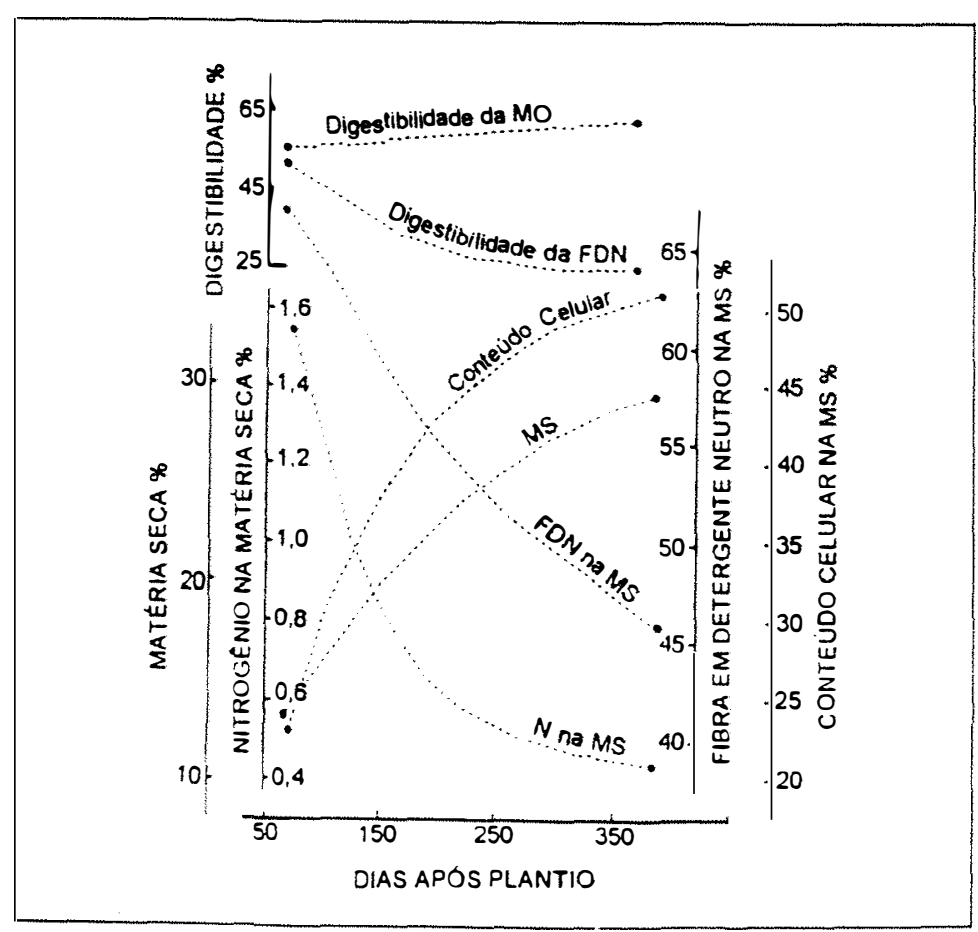

Figura 1. Alterações na composição química da cana-de-açúcar em função da idade da planta (adaptado de Pate, 1977). 
O aumento no valor nutritivo da cana-de-açúcar com o avanço da maturidade, em função principalmente do acúmulo de açúcares, foi evidenciada por Montepellier \& Preston (1977a). Estes pesquisadores encontraram correlação positiva $\left(r^{2}=0,66\right)$ entre os graus Brix do suco e a digestibilidade da MS da cana-de-açúcar. Resultado semelhante foi obtido também por Ferreiro \& Preston (1977) que encontraram correlação positiva $\left(r^{2}=0,92\right)$ entre a digestibilidade da MS e graus Brix, quando esse foi expresso em porcentagem da MS.

Esses dados indicam, portanto, que o valor nutritivo da cana-de-açúcar aumenta à medida que aumenta a concentração de sacarose, o que ocorre quando a planta atinge a maturação e máxima produção de MS. A maioria das gramíneas tropicais apresentam um comportamento totalmente inverso, com menor valor nutritivo associado aos estágios mais avançados de crescimento. Essa característica da cana-de-açúcar faz com que essa forrageira apresente valor nutritivo mais alto, justamente na época em que as demais gramíneas apresentam pequena produção e, muitas vezes, reduzido valor nutritivo.

\subsection{Limitações nutricionais da cana-de-açúcar}

Embora a cana-de-açúcar apresente inúmeras vantagens que a caracterizam como valioso recurso volumoso, vários são os relatos na literatura científica sobre as limitações do ponto de vista do valor alimentar da cana, quando usada como volumoso exclusivo na alimentação de ruminantes.

De acordo com Leng \& Preston (1976), as pesquisas com cana-deaçúcar na alimentação de ruminantes caracterizavam-se pelos variáveis e geralmente baixos niveis de desempenho animal obtidos em relação a digestibilidade da matéria seca (em torno de 63 a 68\%). 
Boin \& Tedeschi (1993) ressaltaram que a cana apresenta baixo valor alimentar, uma vez que caracteriza-se por ser desbalanceada em termos de nutrientes exigidos tanto pelos ruminantes, quanto pelos microrganismos ruminais.

Conforme salientou Faria (1993), a cana deve ser considerada como um alimento desequilibrado, ocasionando problemas de baixo consumo e deficiências nutricionais, quando existe a tentativa de fornecimento exclusivo dessa forrageira.

\subsubsection{Baixo teor de nitrogênio}

Uma das principais limitações da cana como alimento para ruminantes é o baixo teor de proteína bruta na matéria seca. Pate (1981) trabalhando com duas variedades de cana-de-açúcar verificou teores de PB de 3,3 e 3,5\% na MS. Boin (1985) reportou valores de PB de 1,8 e 4,7\% na MS, em amostras de cana da Estação Experimental do Instituto de Zootecnia de Sertãozinho e de Ribeirão Preto, respectivamente.

Dietas com baixos teores de PB estão relacionadas com baixa ingestão de matéria seca e desempenho animal. Segundo Van Soest (1994), dietas com concentrações de PB inferiores a $7 \%$ na $M S$, não atendem nem mesmo às exigências de nitrogênio dos microrganismos ruminais, ocasionando prejuízos à fermentação ruminal e redução do consumo de MS.

As exigências de nitrogênio dos microrganismos ruminais são expressas, freqüentemente, em termos de concentração de nitrogênio amoniacal $\left(\mathrm{N}-\mathrm{NH}_{3}\right)$ no fluído ruminal, uma vez que a maioria das bactérias ruminais é capaz de utilizar amônia como fonte de nitrogênio. Satter \& Slyter (1974) verificaram que concentrações de nitrogênio amoniacal de 2,0 a $5,0 \mathrm{mg} / \mathrm{dl}$ foram necessárias 
para promover adequado crescimento microbiano. Leng \& Preston (1976) relataram niveis de $\mathrm{N}-\mathrm{NH}_{3}$ da ordem de 1,0 a $4,0 \mathrm{mg} / \mathrm{dl}$ em animais recebendo dietas à base de cana-de-açúcar sem suplementação com fontes de nitrogênio. Tais evidências indicam que a cana-de-açúcar é incapaz de proporcionar compostos nitrogenados para adequada sintese de proteína microbiana, sem a devida suplementação com fontes protéicas prontamente disponiveis no rúmen.

\subsubsection{Suprimento de nutrientes para o pós rúmen}

A teoria de que as dietas à base de cana-de-açúcar deveriam ser suplementadas com suplementos ricos em amido e proteína que escapassem à degradação ruminal, iniciou-se em razão de trabalhos australianos com forragens com baixos teores de PB terem obtidos bons resultados com esse tipo de suplementação (Preston \& Leng, 1980). Posteriormente, trabalhos com adição de polidura de arroz em dietas com cana e uréia indicaram resultados de elevado desempenho animal com esse tipo de alimento. No experimento de Preston e al. (1976), o tratamento que consistia de cana, uréia (1,3\% da cana fresca) e melaço apresentou ganho de peso vivo de 0,225 kg/dia. Em outro tratamento, em que os animais receberam a mesma dieta, mas foram suplementados com 1,2 kg/dia de polidura de arroz, o ganho de peso foi próximo de 0,900 Kg/dia.

A hipótese para explicar o marcante efeito da polidura de arroz sobre o desempenho de bovinos recebendo dietas à base de cana foi sugerida por Leng \& Preston (1976). Segundo estes autores, o fator que mais limitava o desempenho de animais consumindo dietas à base de cana-de-açúcar era a baixa ingestão de matéria seca de cana-de-açúcar em conseqüência do escasso fornecimento de amido e proteinas para o pós rúmen. Inúmeras 
pesquisas foram, então, desenvolvidas com o propósito de se verificar essa hipótese.

Valdez et al. (1977) estudaram o efeito da polidura de arroz sobre os parâmetros de fermentação ruminal em bovinos em crescimento recebendo dietas à base de cana. Segundo esses pesquisadores, a suplementação com polidura de arroz não alterou os parâmetros de fermentação ruminal, o que sugeria que esse suplemento exercia seus efeitos no pós rúmen.

Posteriormente, os trabalhos de Elliott et al. (1978a) e Elliott et al. (1978b) confirmaram a expectativa inicial de que a polidura de arroz era um suplemento rico em amido e proteina de baixa degradabilidade ruminal. Observou-se nesses experimentos, que a adição de niveis crescentes de polidura de arroz às dietas com cana-de-açúcar resultava em aumento do fluxo de nitrogênio e de polímeros de $\alpha$ - glucose para o duodeno.

Priego et al. (1977) estudaram o efeito de níveis crescentes de polidura de arroz em dietas à base de cana-de-açúcar para bovinos. Verificou-se, que a adição desse suplemento foi responsável por um aumento na ingestão de MS, volume ruminal e taxa de renovação do líquido ruminal. Aumento da taxa de renovação do fluido ruminal e da eficiência de síntese de proteína microbiana em função da adição de polidura de arroz às dietas com cana e uréia foram reportados, posteriormente, por Elliott et al.(1978a).

Com base nesses resultados, Preston \& Leng (1980) sugeriram que o papel da polidura de arroz nas dietas com cana e uréia era: a) sua influência sobre a taxa de renovação do conteúdo ruminal e b) fornecimento "extra" de energia para o animal hospedeiro, através da digestão de amido no intestino.

Um aumento na taxa de passagem da digesta ruminal pode trazer benefícios ao desempenho animal ao aliviar o rúmen, permitindo aumento na ingestão de MS, ou por aumentar a eficiência de síntese de proteína 
microbiana (Owens \& Goetsch, 1986). A relação entre esses eventos é, no entanto, bastante complexa. Conforme salientaram Sniffen \& Robinson (1987), existem poucas evidências para sugerir que a eficiência de sintese de proteína microbiana possa ser aumentada in vivo, apenas quando a taxa de renovação da fase líquida é estimulada. Hugues-Jones et al. (1981) trabalhando com novilhos recebendo dietas de cana suplementada com uréia, observaram taxas de passagem de 2,2 a 4,6\%/h. Essas taxas são semelhantes às reportadas por Aroeira et al. (1993b), que encontraram valores de taxa de passagem da cana de açúcar 3,1 e $3,2 \% / h$ em novilhos mestiços consumindo dietas à base de cana, uréia e suplementados com farelo de algodão e de arroz, respectivamente.

A hipótese de Preston \& Leng (1980) sugeria, também, que a polidura de arroz poderia permitir um suprimento extra de energia ao animal através da digestão do amido desse suplemento no intestino. Entretanto, Reynolds et al. (1988) trabalhando com bovinos multicateterizados, reportaram que 0 aparecimento líquido de glucose no sistema porta foi nulo ou insignificante. isso sugere que muito pouco da glucose absorvida a partir da digestão intestinal do amido atinja os músculos e a glândula mamária, já que há extenso uso da glucose pelos órgãos drenados pelo sistema porta (Theurer, 1992). Esse pesquisador concluiu, então, que quase toda glucose requerida para produção de leite deve ser proveniente da gluconeogênese hepática.

Huntington (1994) concluiu que o amido pode ser utilizado mais eficientemente por ruminantes quando extensamente fermentado no rúmen. Pesquisas conduzidas na Universidade do Arizona sumarizados por Simas (1997) têm demostrado efeito positivo do processamento de grãos sobre o desempenho animal em função de um aumento da quantidade de amido degradado no rúmen. 
Ao contrário do que foi proposto por Leng \& Preston (1976), pesquisas mais recentes sugerem que, se o objetivo na suplementação das dietas com cana e uréia for fornecer energia para funções produtivas, fontes de amido mais degradáveis no rúmen devem trazer mais benefícios do que aquelas de baixa degradabilidade ruminal.

Quanto ao possivel efeito da proteína de baixa degradabilidade ruminal existente na polidura de arroz, nota-se que essa deve ter pequena contribuição sobre a quantidade total de aminoácidos que atingem o intestino, uma vez que o teor de PB da polidura de arroz é da ordem de 13 a 15\%. Clark et al. (1992) verificaram em uma série de pesquisas, que o fluxo de nitrogênio não amoniacal (NNA) para o intestino só foi aumentado, em dietas que utilizaram proteína de baixa degradabilidade ruminal, em relação à dietas com farelo de soja, quando essas fontes contribuíram com mais de 35\% da PB da dieta.

Silvestre et al. (1976) reportaram que experimentos que utilizaram suplementos protéicos como farinha de peixe ou de carne (ricos em proteina de baixa degradabilidade) falharam em obter bons resultados de desempenho em dietas à base de cana-de-açúcar. Santos (1997) reuniu trabalhos do período de 1984 a 1995 sobre proteína não degradável no rúmen e observou que em 83\% das comparações, onde o farelo de soja foi substituído por fontes de PB pouco degradáveis no rúmen, não houve aumento na produção de leite e no teor da proteina do leite. Observou, também, que a inclusão dessas fontes protéicas resultou em limitação das frações nitrogenadas para sintese de proteína microbiana no rúmen e limitou também o fluxo de proteína para o duodeno. 


\subsubsection{Digestibilidade da fração fibrosa}

O baixo desempenho animal obtido com dietas à base de cana-deaçúcar tem sido atribuído ao baixo consumo de matéria seca, associado não apenas ao baixo teor de $\mathrm{PB}$, mas também à reduzida digestibilidade da fração fibrosa dessa forrageira.

Valdez et al. (1977) verificaram que a digestibilidade da fração fibrosa da cana-de-açúcar era de apenas $19,5 \%$. Preston \& Leng (1980) sugeriram que a baixa taxa de digestão da fração fibrosa da cana, com conseqüente aumento no tempo de retenção no rúmen, poderiam explicar o baixo consumo de matéria seca. Pate (1981), trabalhando com niveis crescentes de cana-de-açúcar na matéria seca das dietas, encontrou correlações significativas $(r=-0,93)$ entre a porcentagem de cana na dieta e o consumo de matéria seca. Este autor atribuiu a redução do consumo à baixa taxa de digestão e "turnover" da fibra da cana-de-açúcar no rúmen.

Aroeira et al. (1993b) reportaram valores médios de degradabilidade efetiva e tempo de retenção no rúmen da FDN da cana-de-açúcar de $24,6 \%$ e $32,4 \mathrm{~h}$ em novilhos alimentados com cana, uréia e suplementados com farelo de arroz ou algodão. Degradabilidade efetiva da FDN da cana de $25,87 \%$ foi constatada por Aroeira et al. (1993c). que concluíram ser a baixa degradabilidade da fibra, o fator mais limitante para o consumo de MS e desempenho dos animais alimentados com dietas à base de cana-de-açúcar.

Elevados teores de FDN indigestivel têm sido associados ao baixo consumo de MS em dietas com cana-de-açúcar (Figueira et al., 1993). Teores de FDN indigestivel de 54,9 e 57,1 foram observados por Aroeira et al. (1993b) em novilhos recebendo, cana, uréia e farelo de arroz e algodão, respectivamente. 
nele retidos. Esses autores explicaram, ainda, que esses microrganismos engolfam e utilizam as bactérias, resultando na redução da proteína microbiana disponivel para o animal hospedeiro. Conforme Figueiredo (1990) dietas a base de cana-de-açúcar favorecem a proliferação de protozoários no rúmen, em função da manutenção de elevado pH ruminal, conjugado à grande disponibilidade de carboidratos solúveis no rúmen.

Outro fator que tem limitado o desempenho de bovinos alimentados com cana é o baixo conteúdo em minerais e vitaminas, como destacado por Boin (1985). No entanto, a extensão desse problema ficará na dependência do conteúdo mineral e vitamínico dos suplementos usados com esse alimento.

\subsection{Suplementação de dietas com cana-de-açúcar}

\subsubsection{Aspectos gerais}

Os resultados de estudos com cana-de-açúcar na alimentação de ruminantes têm demonstrado que essa forrageira não permite elevado desempenho sem que devidas correções nas dietas sejam feitas para superar suas limitações nutricionais. Conforme explicaram Boin \& Tedeschi (1993) a suplementação racional da cana deveria ser feita em duas fases: em primeiro lugar atender às exigências mínimas dos microrganismos ruminais e em segundo, atender às exigências dos animais alimentados em função dos níveis de desempenho esperado. Essas informações confirmam que a maximização da fermentação ruminal deve ser um objetivo prioritário da suplementação das dietas com cana-de-açúcar. 
Baixos coeficientes de digestibilidade aparente da fração fibrosa da cana-de-açúcar no trato digestivo total foram verificados por Rodriguez et al. (1993). A digestibilidade da FDN da cana no trato total relatados por esses pesquisadores variaram de 31,98 a $37,48 \%$ conforme 0 tratamento utilizado. Aroeira et al. (1993a) observaram valores semelhantes, com coeficientes de digestibilidade da FDN e da FDA no trato total de 35,8 e $39,7 \%$ e de 32,7 e $34,2 \%$, respectivamente.

Em dietas com grande proporção de forragens, o conteúdo de FDN é considerado como um dos principais fatores limitando o consumo de MS, envolvendo interações entre enchimento e distensão do rúmen, tempo disponivel para ingestão e densidade calórica (Van Soest, 1994). Conforme salientaram Dado \& Allen (1995), a FDN deve ser a fração da dieta associada às propriedades de enchimento do trato digestivo em ruminantes consumindo dietas ricas em forragens.

Embora a digestibilidade da fração fibrosa nem sempre se correlacione com a ingestão de MS (Van Soest, 1994), evidências de que a digestibilidade da FDN possa afetar o consumo de MS e a produção de leite foram relatadas por Allen \& Oba (1997). Esses pesquisadores analisaram 27 artigos publicados no Journal of Dairy Science, relacionando o efeito da digestibilidade da FDN sobre o desempenho animal e verificaram aumentos significativos no consumo de MS e produção de leite em função da maior digestibilidade da fibra.

\subsubsection{Outras limitações}

Segundo Preston \& Leng (1980), os protozoários predominantes em dietas a base de cana-de-açúcar (Isotricha e Dasytricha spp.) tendem a se acumular nas porções mais profundas do rúmen, sendo então, seletivamente 


\subsubsection{Suplementação com uréia em dietas com cana-de-açúcar}

As dietas com cana-de-açúcar necessitam, conforme salientado anteriormente, ser suplementadas com fontes de proteina ou NNP para atender às exigências de nitrogênio dos microrganismos ruminais e do animal hospedeiro. A uréia tem sido a principal fonte de $\mathrm{N}$ utilizada para corrigir $\mathrm{O}$ baixo teor de PB das dietas à base de cana. Segundo Huber (1984), as melhores rações para se incorporar NNP são aquelas com elevado teor de energia e baixo teor de nitrogênio. Isso explica o grande potencial de utilização da uréia nas dietas à base de cana-de-açúcar, ricas em carboidratos prontamente fermentáveis (sacarose) e com baixos teores de PB.

Um dos trabalhos pioneiros sobre teores de uréia em dietas com canade-açúcar na alimentação de bovinos foi desenvolvido por Alvarez \& Preston (1976). Esses pesquisadores trabalharam com concentrações crescentes de uréia $(0,0: 0,375 ; 0,75 ; 1,125$ e $1.5 \%$ do peso fresco da cana) em novilhos de corte $(186,0 \pm 90 \mathrm{~kg})$ consumindo dietas à base de cana-de-açúcar, melaço e suplementados com $1,0 \mathrm{~kg} / \mathrm{dia}$ de polidura de arroz. Os resultados desse experimento mostraram que o teor mais alto de uréia $(1,5 \%$ do peso da cana fresca) proporcionou o maior ganho de peso $(0,586 \mathrm{~kg} / \mathrm{dia})$, a maior ingestão de MS (2,67\% do peso vivo) e a melhor conversão alimentar (10,3 kg MS/kg ganho). Os autores reportaram, ainda, que esse teor de uréia na dieta era equivalente a $40,0 \mathrm{~g}$ de $\mathrm{N} / \mathrm{kg}$ de $\mathrm{MS}$ digerida ( $61 \%$ de digestibilidade) e que este valor era próximo do valor de $35,0 \mathrm{~g}$ de N/kg de MS digerida, considerado como ótimo, por Satter \& Slytter (1974).

Preston et al. (1976) trabalharam com bovinos de corte em crescimento recebendo dietas à base de cana-de-açúcar, melaço, uréia (fixada em torno de $1,3 \%$ do peso da cana fresca) e suplementados com diferentes quantidades de 
polidura de arroz $(0,0 ; 0,3 ; 0,6 ; 0,9$ e $1,2 \mathrm{~kg} / \mathrm{dia})$. Conforme reportaram os autores, animais que não receberam o suplemento apresentaram ganho de peso vivo de 0,225 kg/dia, enquanto os que receberam 1,2 kg/dia de polidura de arroz apresentaram ganhos de peso vivo de até 0,896 kg/dia.

Apesar dos teores de uréia de 1,3 e 1,5\% do peso fresco da cana terem proporcionado bons resultados de desempenho animal nos experimentos supracitados, em trabalhos posteriores de revisão sobre cana-de-açúcar na alimentação de ruminantes, os autores sugeriram que o teor de uréia mais adequado era de $1,0 \%$ em relação ao peso da cana fresca. Preston (1977) relatou que o teor de uréia mais adequado era de $30 \mathrm{~g} / \mathrm{kg}$ de $\mathrm{MS}$ de cana, muito próximo de $1 \%$ da cana fresca, já que a umidade dessa forrageira situa-se em torno de 75 a $70 \%$ nos estágios mais avançados de maturação. Preston \& Leng (1978) recomendaram, em um artigo sobre aplicação prática e econômica da cana-de-açúcar como alimento para bovinos, a suplementação de uréia na proporção de $10 \mathrm{~g} / \mathrm{kg}$ de cana fresca, ou seja, 1,0\%.

Esta aparente contradição deve-se, em parte, ao fato de que as pesquisas daquela época enfatizaram que o suprimento de nutrientes para 0 pós rúmen (polidura de arroz) era mais determinante para o consumo de MS e ganho de peso vivo de bovinos que o teor de uréia na dietas. Além disso, o teor de $1 \%$ de uréia em relação ao peso da cana fresca supera em muito as recomendações de fornecimento de uréia para ruminantes recebendo outros volumosos em paises de clima temperado.

Huber \& Kung Jr. (1981) reportaram que a uréia deveria ser fornecida na proporção de 45 a $50 \mathrm{~g}$ para cada $100 \mathrm{~kg}$ de peso vivo de forma a evitar intoxicação, embora salientassem que animais bem adaptados pudessem suportar niveis duas ou até três vezes superiores a esse limite. Aroeira et at. (1995) trabalharam com vacas mestiças em lactação (483 $\mathrm{kg}$ de peso vivo) 
consumindo dietas à base de cana-de-açúcar, adicionada com uma mistura uréia e sulfato de amônio ( $1,0 \%$ do peso fresco da cana), suplementadas com farelo de algodão e concentrado. Esses pesquisadores verificaram consumos de cana da ordem de $34,8 \mathrm{~kg} / \mathrm{dia}(8,7 \mathrm{~kg}$ de $\mathrm{MS}$ com $25 \%$ de $\mathrm{MS}$ ), o que corresponde a um consumo de $348 \mathrm{~g} /$ dia de uréia, ou uma ingestão de $72 \mathrm{~g}$ de uréia para cada $100 \mathrm{~kg}$ de peso vivo. Tal quantidade excede o limite proposto por Huber \& Kung Jr. (1981), uma vez que uma vaca de $483 \mathrm{~kg}$ deveria consumir entre 217 a $242 \mathrm{~g}$ de uréia/dia.

Outra provável explicação para esta aparente contradição, baseia-se no fato de que teores de uréia acima de 1,0\% nas dietas com cana-de-açúcar não refletiram em alterações significativas na digestibilidade da MS no trato total.

Ferreiro et al. (1977b) trabalharam com 4 teores de uréia $(0,0 ; 1,0 ; 1,3$ e $1,6 \%$ do peso da cana fresca) em novilhos mestiços consumindo dietas com cana e reportaram que, embora a digestibilidade aparente da MS tenha sido numericamente superior no tratamento com $1,6 \%$ de uréia na cana fresca, não se observaram diferenças significativas entre este e os outros dois tratamentos que incluíam uréia. Montpellier \& Preston (1977a) trabalharam com bovinos de corte alimentados com dietas à base de cana-de-açúcar (apenas colmos) suplementadas com uréia na proporção de $11,0 \mathrm{~g}$ de uréia/kg de colmo fresco. A média dos coeficientes de digestibilidade aparente da MS no trato total reportada por estes pesquisadores foi de $67,4 \%$. Ferreiro \& Preston (1977) estudaram $o$ efeito de diferentes proporções de pontas e colmos de cana-deaçúcar sobre a digestibilidade da MS em dietas de bovinos de corte contendo uréia ( $8,8 \mathrm{~g}$ de uréia/kg de cana) e melaço. A digestibilidade aparente da MS foi de $63,9 \%$ para o tratamento com $75 \%$ de colmos e $25 \%$ de pontas. Ferreiro et al. (1977a) reportaram um coeficiente de digestibilidade aparente da MS de $62,14 \%$ para dietas com colmo de cana, misturado a uréia $(11 \mathrm{~g} / \mathrm{kg}$ de colmo 
fresco) em bovinos suplementados com $0,5 \mathrm{~kg} / \mathrm{dia}$ de polidura de arroz. Montpellier \& Preston (1977b) reportaram coeficientes de digestibilidade aparente da MS de 60,3\% para dietas com cana-de-açúcar integral suplementadas com 14,2 g de uréia/kg de cana fresca em bovinos de corte cruzados. Mais recentemente, Rodriguez et al. (1993) reportaram coeficientes de digestibilidade aparente da MS no trato total de 57,19; 57,61 e 60,34\% em bovinos de corte mestiços alimentados com dietas à base de cana-de-açúcar ( $85 \%$ da MS), farelo de algodão ( $15 \%$ da MS), contendo teores de uréia de 1,0; 1,5 e 2,0\% sobre peso da cana fresca, respectivamente. Os autores não observaram diferenças significativas na digestibilidade aparente da MS no trato total em função dos niveis de uréia empregados. Aroeira et al. (1993a) verificaram digestibilidade aparente da MS no trato total de 66.7 e $62,7 \%$ em novilhos recebendo dietas à base de cana, uréia ( $1,0 \%$ do peso fresco) e farelo de algodão ou arroz, respectivamente. Um sumário dos resultados desses experimentos são mostrados na Tabela 1.

Verifica-se, através da análise dos dados da Tabela 1, que os teores de uréia utilizados variaram de 0,88 a 2,0\% de uréia em relação ao peso da cana fresca, não se observando resultados consistentes de aumento na digestibilidade aparente da MS no trato total em função do aumento teor de uréia das dietas.

Conforme salientaram Preston \& Leng (1980), a inclusão das pontas em dietas com cana permite maior consumo de MS e maior desempenho, apesar dessa fração da cana apresentar menor digestibilidade da MS que os colmos. Segundo esses autores, o efeito da inclusão das pontas deve estar relacionado a um aumento no volume ruminal e na taxa de passagem da digesta. Além disso, esses pesquisadores especularam que o fornecimento de fibras longas poderia proporcionar um ambiente ruminal mais favorável, permitindo que os 
microrganismos ruminais sejam mais eficientes em tornar os nutrientes mais disponíveis para os animais.

Tabela 1. Efeito do teor de uréia sobre a digestibilidade aparente da matéria seca no trato total, em bovinos alimentados com dietas à base de cana-deaçúcar.

\begin{tabular}{cccc}
\hline $\begin{array}{c}\text { Uréia } \\
\text { (\% da cana fresca) }\end{array}$ & $\begin{array}{c}\text { DAMSTT } \\
(\%)\end{array}$ & Dieta & Autores \\
\hline 1,00 & 68,97 & colmos picados & Ferreiro et al. (1977b) \\
1,60 & 71,61 & & \\
1,10 & 67,4 & colmos picados & Montpellier \& Preston (1977a) \\
0,88 & 63,9 & $75 \%$ colmo e 25\% & Ferreiro \& Preston (1977) \\
& & ponta picados & \\
1,10 & 62,14 & colmos picados + 0,5 & Ferreiro et al. (1977a) \\
& & kg de polidura de arroz & \\
1,42 & 60,3 & cana integral picada & Montpellier \& Preston (1977b) \\
1.00 & 57,19 & cana integral picada e & Rodriguez et al. (1993) \\
1,50 & 57,61 & farelo de algodão & \\
2,00 & 60,34 & & \\
& & cana integral picada & Aroeira et al. (1993a) \\
1,00 & 66,7 & farelo de algodão & \\
1,00 & 62,7 & farelo de arroz &
\end{tabular}

${ }^{1}$ Digestibilidade aparente da matéria seca no trato total

Poucas pesquisas daquela época se propuseram a estudar o efeito do teor de uréia sobre a digestibilidade da fração fibrosa, a qual parece ser um dos principais fatores afetando consumo de MS em dietas com cana. Pesquisas 
mais recentes têm se dedicado, entretanto, a analisar essa restrição das dietas com cana-de-açúcar.

Avaliando o efeito de diferentes teores de uréia $(1,0 ; 1,5$ e 2,0\% do peso da cana fresca) sobre a degradabilidade in situ dos nutrientes da cana-deaçúcar, Aroeira et al. (1993c) reportaram uma tendência $(P<0,10)$ de aumento na degradabilidade efetiva da FDN para os teores de 1,5 e 2,0\% de uréia. Para os tratamentos com 1,$0 ; 1,5$ e $2,0 \%$ de uréia, os coeficientes de degradabilidade efetiva foram 23,$96 ; 26.74$ e $26,90 \%$, respectivamente. As taxas de degradação da FDN da cana foram de $2,80 \% / h$ para o tratamento com $1,0 \%$ de uréia e de 4,30 e $4,10 \% /$ para os tratamentos com 1,5 e 2,0\% de uréia, o que significa um aumento de $50 \%$ em média.

Rodriguez et al. (1993) trabalharam com novilhos mestiços recebendo dietas à base de cana-de-açúcar ( $85 \%$ MS), farelo de algodão (15\% da MS) e uréia $(1,0 ; 1,5$ e 2,0\% do peso fresco da cana). Os autores verificaram um efeito linear positivo significativo $(P<0,05)$ do teor de uréia sobre a digestibilidade aparente da FDA no trato total.

Figueira et al. (1993) estudaram a dinâmica ruminal e pós ruminal da cana-de-açúcar em bovinos mestiços consumindo dietas à base de cana (85\% MS), farelo de algodão (15\% da MS) e uréia (1,0;1,5 e 2,0\% do peso fresco da cana). Esses pesquisadores notaram que o tempo de retenção da FDN da cana no rúmen no tratamento com $1,5 \%$ de uréia $(27,89 \mathrm{~h})$ foi, significativamente, inferior ao do tratamento com 2,0\% de uréia $(30,65$ h). No entanto, não existiram diferenças significativas entre os tratamentos com $1,0 \%$ e $1,5 \%$ de uréia.

Aroeira et al. (1993a) reportaram coeficientes de digestibilidade aparente da FDN no trato total de $39,7 \%$ e da FDA de $34,2 \%$ em novilhos recebendo dietas à base de cana-de-açúcar ( $85 \%$ da MS), farelo de algodão (15\% da MS) 
e uréia $(1,0 \%$ do peso da cana fresca). No tratamento em que o farelo de algodão foi substituído pelo farelo de arroz (15\% da MS) foram reportados coeficientes de digestibilidade da FDN no trato total de $35,8 \%$ e de FDA de $32,7 \%$. Não foram notadas diferenças na digestibilidade da fração entre os dois tratamentos em função do tipo de suplemento utilizado.

Aroeira et al. (1995) trabalharam com vacas mestiças em lactação alimentadas com dietas à base de cana-de-açúcar, uréia $(1,0 \%$ do peso da cana fresca) e suplementadas com concentrado $(2,0 \mathrm{~kg} / \mathrm{dia})$ e farelo de algodão $(1,0 \mathrm{~kg} / 3,0$ I de leite, para produções de leite acima de 7,0 l/dia). Os autores relataram coeficientes de digestibilidade aparente da FDN e da FDA no trato total de 66,6 e $65,4 \%$, respectivamente. Os autores salientaram que esses coeficientes de digestibilidade foram obtidos com a estimativa da produção de fezes através do óxido de cromo e eram maiores que os reportados na literatura.

Considerando-se que a função prioritária da suplementação em dietas com cana é maximizar a fermentação ruminal, o conhecimento das exigências dos microrganismos ruminais deveria ser considerado, ao se estabelecer recomendações sobre o teor de uréia das dietas à base de cana-de-açúcar.

A utilização eficiente do nitrogênio da uréia como de qualquer outra fonte de proteína pelas bactérias ruminais pressupõe a existência de adequada presença de energia disponivel para esses microrganismos. Excessiva quantidade de $\mathrm{N}$ em relação a energia disponivel para os microrganismos deve ocasionar uma situação em que a taxa de liberação de amônia no rúmen exceda sua taxa de utilização pelas bactérias ruminais, aumentando sua absorção e excreção de $\mathrm{N}$ via uréia (Russell et al. 1992). De acordo com Owens \& Zinn (1988), o catabolismo de nitrogênio não ocorre, no entanto, sem custos para o animal. De acordo com Tyrrell (1970) citado por Van Soest 
(1994), para cada 1,0 g de $\mathrm{N}$ excretado como uréia na urina, ocorre uma perda de energia teórica de 12,0 kcal.

Ferreiro et al. (1977c) sugeriram que o teor adequado de inclusão de uréia em dietas com cana-de-açúcar deveria ser baseado na quantidade de carboidratos rapidamente fermentáveis (o que na cana representa a sacarose acumulada nos colmos). De acordo com esses pesquisadores, a inclusão de uréia nas dietas com cana não deveria obedecer um nivel fixo, uma vez que a quantidade de sacarose pode alterar-se em função da maior precipitação (época de chuvas), estágio de maturidade e variedades diferentes. Eles criaram, então, uma fórmula que pudesse prever, de modo mais racional, a quantidade adequada de uréia em função da quantidade de açúcares solúveis (graus Brix) no suco da cana, assumindo que essa fração representa a principal fonte de carboidratos fermentáveis na cana. Na equação proposta por Ferreiro et al. (1977c) a quantidade de uréia é dada por:

$U=\frac{0,6 \times B \times(94,81-1,12 \times B)}{100-B} \quad$ onde:

$U=$ quantidade de uréia ( $\mathrm{g} / \mathrm{kg}$ de cana fresca),

$B=$ graus Brix no suco da cana.

A equação acima assume algumas suposições (30 g de $\mathrm{N} / \mathrm{kg}$ de carboidrato fermentado e uréia $=48,0 \%$ de $N$ ) que não devem ser válidas para todas as situações. Normalmente, a uréia apresenta 45 a $46 \%$ de N. Sniffen \& Robinson (1987) reportaram que a eficiência de sintese de proteína microbiana ( $g$ de $\mathrm{N}$ microbiano/kg de carboidrato fermentado) pode variar por uma série de fatores, tais como ingestão de MS, taxa de renovação ruminal, relação volumoso : concentrado, fonte de carboidrato e proteína na dieta. Contudo, 
essa fórmula representa um progresso em relação a outras estimativas mais empíricas. Para a utilização da formula é preciso, no entanto, o conhecimento dos graus Brix do suco da cana, tornando necessário o uso de um refratômetro de campo para realizar tais medições.

Conforme já salientado, freqüentemente, as exigências de nitrogênio dos microrganismos ruminais é expressa como concentração de $\mathrm{N}-\mathrm{NH}_{3}$ no fluído ruminal, desde que a maioria das bactérias ruminais utiliza amônia como fonte de $\mathrm{N}$. Infelizmente, os estudos que se preocuparam em estabelecer qual a concentração adequada de $\mathrm{N}^{-\mathrm{NH}_{3}}$ que permitisse eficiente crescimento microbiano apresentam resultados bastante variáveis. Satter \& Slyter (1974) relataram que concentrações de 2,0 a $5,0 \mathrm{mg}$ de $\mathrm{N}-\mathrm{NH}_{3} / \mathrm{dl}$ foram suficientes para maximizar a fermentação microbiana, em estudo in vitro. Mehrez et al. (1977) verificaram que concentrações da ordem de 20 a $22 \mathrm{mg}$ de $\mathrm{N}-\mathrm{NH}_{3} / \mathrm{dl}$ de fluído ruminal foram necessárias para maximizar a fermentação microbiana.

Valores médios acima de $20,0 \mathrm{mg}$ de $\mathrm{N}-\mathrm{NH}_{3} / \mathrm{dl}$ de fluído ruminal foram reportados por Valdez et al. (1977) em bovinos recebendo cana-de-açúcar, melaço e uréia ( $=14,2 \mathrm{~g} / \mathrm{Kg}$ de cana fresca). Mesmo com essas altas concentrações de amônia ruminal, os pesquisadores reportaram baixa degradabilidade da fibra no rúmen. Rodriguez et al. (1993) observaram diferenças significativas $(P<0,05)$ para concentração de amônia ruminal ( $N$ $\mathrm{NH}_{3}$ ) em função do teor de uréia utilizado nas dietas com cana. Para os tratamentos com 1,0; 1,5 e 2,0\% de uréia sobre o peso fresco da cana, as concentrações de amônia ruminal foram, respectivamente, 25,21; 34,93 e 46,05 $\mathrm{mg} / \mathrm{dl}$ de fluido ruminal. De acordo com esses pesquisadores, maiores concentrações de ácidos graxos voláteis foram observadas para os tratamentos com 1,5 e $2,0 \%$ de uréia, o que sugere que concentrações de amônia ruminal 
mais elevadas foram necessárias para promover maior atividade dos microrganismos.

Dietas à base de cana são consideradas como dietas com alta proporção de forragem, em que se acredita, normalmente, existir um grande predomínio de bactérias celulolíticas. Conforme Russell et al. (1992), tais bactérias utilizam apenas amônia como fonte de nitrogênio. Parece lógico, portanto, que atendendo-se as exigências de nitrogênio das bactérias celulolíticas, a partir da uréia hidrolizada no rúmen, resolver-se-ia o problema. No entanto, conforme já se salientou, uma enorme massa de microrganismos ruminais, em animais mantidos com dieta de cana-de-açúcar, é representada por protozoários. Estes microrganismos, não utilizam amônia como fonte de $\mathrm{N}$, necessitando absorver peptídeos e aminoácidos, através do engolfamento e lise das bactérias ruminais. A predação de bactérias por protozoários deve ocasionar uma redução na eficiência de síntese de proteína microbiana, em função de grande reciclagem de bactérias no rúmen (Russell et al., 1992).

Conforme explicou Van Soest (1994), bactérias celulolíticas necessitam além de amônia, fatores de crescimento, como ácidos graxos de cadeia ramificada (isobutírico, isovalérico e 2-methilbutiríco), os quais são formados a partir da degradação de aminoácidos de cadeia ramificada (valina, leucina e isoleucina).

Apesar de quase $80 \%$ das bactérias ruminais serem capazes de utilizar amônia como fonte de nitrogênio (Russell et al., 1992), para algumas cepas de bactérias celulolíticas, aminoácidos e peptídeos são superiores em relação a amônia para maximizar a digestão de fibra (Hoover et al., 1986). Hoover \& Stokes (1991) relataram dados em que a concentração de peptídeos no fluído ruminal de vacas leiteiras, recebendo dietas com 14,4 a $20,6 \%$ de PB, atingiu valores de 84,0 a $154,0 \mathrm{mg} / \mathrm{l}$. Esses autores salientaram que, em experimentos 
com meio de cultura em que se utilizou caseína, concentrações da ordem de $2100 \mathrm{mg} / \mathrm{l}$ foram necessárias para maximizar o crescimento microbiano. Hoover \& Stokes (1991) concluíram, então, que ótimas taxas de crescimento microbiano são, aparentemente, dependentes da disponibilidade de formas orgânicas de nitrogênio.

Conforme relataram Russell et al. (1992), em bactérias que fermentam carboidratos não estruturais, $66 \%$ do $\mathrm{N}$ é proveniente de peptídeos e aminoácidos, enquanto $34 \%$ do $N$ é proveniente da amônia, quando há disponibilidade de carboidratos não estruturais no meio. Embora as dietas com cana-de-açúcar apresentam uma considerável proporção de carboidratos constituintes da parede celular, tais dietas apresentam uma enorme quantidade de açúcares solúveis, principalmente, sacarose. Em um estudo realizado para avaliar-se a degradabilidade in situ da cana-de-açúcar, Aroeira et al. (1993b) verificaram que $55,2 \%$ da MS da cana foi imediatamente solubilizada, fração esta que correspondia à sacarose da cana-de-açúcar, segundo os autores.

Tais evidências sugerem que a eficiência de síntese de proteína microbiana poderia estar sendo limitada, em dietas com cana-de-açúcar e uréia, pela ausência ou pequena disponibilidade de formas orgânicas de nitrogênio (proteína verdadeira).

Em dietas com cana-de-açúcar, a suplementação com uma mistura de uréia e sulfato de amônio (9:1) na concentração de 1,0\% do peso da cana fresca tem sido a recomendação prática seguida até os dias atuais por pesquisadores da Escola Superior de Agricultura "Luiz de Queiroz" - ESALQ (Silva, 1993) e do Centro Nacional de Pesquisa de Gado de Leite - CNPGL da EMBRAPA (Oliveira, 1985). As recomendações também incluem a suplementação com fontes de proteína e amido de baixa degradabilidade 
ruminal, sem a qual acredita-se ser impossivel a obtenção de bom desempenho animal.

Tais recomendações não consideraram, porém, resultados de pesquisas mais recentes com ruminantes, as quais têm permitido verificar que uma maior digestibilidade da fibra da cana poderia ser obtida com aumento no teor de uréia, ou que a pequena disponibilidade de aminoácidos e peptídeos poderia resultar em decréscimo da eficiência da fermentação ruminal. Além disso, poucas evidências científicas têm suportado, atualmente, que o fornecimento de nutrientes para o pós rúmen possa trazer mais benefícios que maximização da fermentação ruminal. 


\section{MATERIAL E MÉTODOS}

\subsection{Local}

O experimento foi conduzido no estábulo experimental do Departamento de Zootecnia, Setor de Ruminantes, da ESALQ da Universidade de São Paulo, em Piracicaba, no período de outubro a dezembro de 1997.

\subsection{Animais}

Foram utilizadas quatro vacas adultas da raça holandesa, hígidas, não lactantes, com peso médio de $600 \mathrm{~kg}$. As vacas chegaram em agosto de 1997 , quando foram submetidas à cirurgia para colocação de cânulas no rúmen e duodeno. A cânula duodenal apresentava configuração em "T" com 2,5 cm de diâmetro interno e foi inserida a cerca de $10 \mathrm{~cm}$ do piloro. A cânula ruminal foi colocada na região correspondente ao saco caudal do rúmen. Antes do início do experimento, os animais foram pesados em balança com capacidade para $1500 \mathrm{~kg}$ e sensibilidade de $0,020 \mathrm{~kg}$ e submetidos à verimifugação e banho carrapaticida.

Os animais foram alojados em baias individuais com dimensões de 2,11 $\mathrm{m}$ (atrás) $\times 2,10 \mathrm{~m}$ (lateral esquerda) × 1,0 m (frente) $\times 2,37 \mathrm{~m}$ (lateral direita), caracterizando uma disposição trapezoidal. As baias tinham piso de borracha, eram equipadas com bebedouros individuais e automáticos $(22,0 \mathrm{~cm}$ de 
diâmetro) e com cochos de alimentação com dimensões de 0,80 m de largura, $0,57 \mathrm{~m}$ de comprimento, $0,23 \mathrm{~m}$ de altura na frente e $0,52 \mathrm{~m}$ atrás.

\subsection{Delineamento experimental}

O delineamento experimental utilizado foi um quadrado latino $4 \times 4$ (Tabela 2), com os seguintes tratamentos,

- Tratamento A: cana-de-açúcar integral picada com farelo de soja,

- Tratamento B: cana-de-açúcar integral picada com 1,0\% de uréia,

- Tratamento C cana-de-açúcar integral picada com 1,5\% de uréia e,

- Tratamento D cana-de-açúcar integral picada com 2,0\% de uréia.

Tabela 2. Quadrado Latino $4 \times 4$ balanceado para efeito residual, constituido por quatro períodos, quadro vacas e quatro tratamentos.

\begin{tabular}{ccccc}
\hline Período & Vaca 1 & Vaca 2 & Vaca 3 & Vaca 4 \\
\hline I & D & A & B & C \\
II & A & C & D & B \\
III & B & D & C & A \\
IV & C & B & A & D \\
\hline
\end{tabular}

Fonte: Cox (1958)

Cada período experimental foi constituido de 15 dias, sendo 10 dias para adaptação dos animais à nova dieta e 5 dias para coleta. No final de cada período experimental os animais foram pesados. Durante a fase de adaptação, as vacas foram soltas em dias alternados para que pudessem caminhar e tomar sol. 


\subsection{Dietas experimentais}

As dietas do tratamento $A$ e $B$ foram balanceadas para conter cerca de $12 \%$ de $\mathrm{PB}$, de acordo com as exigências para vacas secas do NRC (1989). Utilizou-se o farelo de soja, com objetivo de se comparar a utilização da proteína verdadeira em ralação à uréia. O farelo de soja foi selecionado pelo fato de ser a fonte de proteina verdadeira mais freqüentemente utilizada em dietas para bovinos leiteiros. As dietas dos tratamentos $C$ e $D$ foram formuladas para conter teores mais elevados de uréia do que o recomendado pela literatura, apresentando portanto, teores mais elevados de PB.

A suplementação mineral foi feita sob a forma de "top dress" (cobertura), sendo colocadas $100 \mathrm{~g}$ do suplemento mineral Phos Milk ${ }^{\circledR}$ - Agromix por refeição e após a homogeneização da cana com a uréia ou com o farelo de soja. Os niveis de garantia dos minerais em $1,0 \mathrm{~kg}$ do suplemento mineral eram: $\mathrm{P}(73,0 \mathrm{~g}), \mathrm{Ca}(130,0 \mathrm{~g}), \mathrm{Mg}(15,0 \mathrm{~g}), \mathrm{S}(25,0 \mathrm{~g}), \mathrm{Na}(156,0 \mathrm{~g}), \mathrm{Cl}(249,0$ g), Zn (5000 mg) Cu (1500 mg), Fe (2500 mg), Mn (1000 mg), Co (120 mg), I (180 mg), Se (30,0 mg) e F (730 mg - máximo).

As dietas foram fornecidas 2 vezes por dia às 8:00 e 20:00 hs, sendo realizado um acompanhamento diário da qualidade da cana, analisando-se os graus Brix através de um refratômetro manual de campo (Toko ${ }^{\circledR}$ com escala de o a $32^{\circ}$ e sensibilidade de $0,2^{\circ}$ ). A partir do sexto dia de cada período experimental, em cada refeição, os animais receberam um envelope de papel contendo $25,0 \mathrm{~g}$ de óxido de cromo, via fístula ruminal, perfazendo um total de 50.0 g/dia de óxido de cromo. O consumo alimentar foi acompanhado diariamente e a quantidade de cana oferecida foi calculada para permitir sobras de alimento no cocho $( \pm 10 \%$ do oferecido). 
A cana-de-açúcar foi colhida manualmente em dias alternados e armazenada em local coberto, próximo ao estábulo experimental. Na hora das refeições, a cana-de-açúcar foi despalhada e picada juntamente com as pontas em desintegrador - picador elétrico $\left(\right.$ Nogueira $^{\circledR}$ : modelo DPM - 4). Depois de picada uma quantidade suficiente para os quatro animais, homogeneizava-se toda a cana e, durante o periodo de coleta, amostrava-se uma quantidade fixa de cana em cada refeição. Estas amostras foram, então, compostas por período e colocadas em freezer $\left(-20^{\circ} \mathrm{C}\right)$, para posterior análise bromatológica.

A quantidade de cana destinada para cada vaca foi pesada em balança Marte $^{\circledR}$, modelo LC 100 , para carga máxima de $100 \mathrm{~kg}$ e precisão de $50,0 \mathrm{~g}$. As quantidades de uréia correspondentes às concentrações de 1,0; 1,5 e 2,0\% do peso da cana fresca eram pesadas (balança Marte ${ }^{\circledR}$, modelo AS 5500, para até 5,0 kg e precisão de 0,01 g) e misturadas ao sulfato de amônio na proporção de 9:1 (9 partes de uréia: 1 parte de sulfato de amônio). Essa mistura era diluida em água (1,0 kg de mistura para 4,0 I de água) e, com o auxílio de um regador, adicionada à cana triturada diretamente no cocho de alimentação.

A mistura da cana picada com o farelo de soja foi realizada considerando-se a prévia análise de MS e teor de PB do farelo de soja. O farelo de soja foi pesado na mesma balança em que foi pesada a cana-deaçúcar e fornecido na hora das refeições, misturando-se este suplemento com a cana-de-açúcar.

Quantidades fixas das dietas oferecidas $(5,0 \%$ do peso fresco) foram amostradas para cada animal, em cada refeição e compostas por vaca e período para posterior análise bromatológica. O consumo alimentar foi registrado diariamente. As sobras foram retiradas do cocho duas vezes ao dia, sendo então pesadas, amostradas ( $5 \%$ do total), agrupadas por vaca e por periodo e congeladas $\left(-20^{\circ} \mathrm{C}\right)$, para posterior análise bromatológica. 


\subsection{Coleta de conteúdo duodenal, fezes e urina}

A avaliação da digestibilidade aparente da MS e demais nutrientes no trato total foi feita mediante pesagem do total das fezes produzidas pelos animais. Foram utilizados também dois marcadores, sendo um externo (óxido de cromo) e outro interno (lignina) para se obter os coeficientes de digestibilidade dos nutrientes nos pré-estômagos, via coleta do conteúdo duodenal e posterior análise da concentração dos marcadores.

As fezes dos animais foram coletadas diariamente do nono até o décimo quinto dia de cada período com auxilio de caixotes metálicos revestidos de borracha, os quais eram colocados abaixo do nivel do piso, na região posterior do animal. As fezes foram pesadas duas vezes por dia (7:00 e 19:00 hs), homogeneizadas e amostradas em $5 \%$ do total de cada pesagem. Estas amostras foram congeladas $\left(-20^{\circ} \mathrm{C}\right)$ e agrupadas por período e vaca, para posterior análise.

O conteúdo duodenal foi coletado nos primeiros quatro dias do periodo de coleta em intervalos de quatro horas. Os horários de cada amostragem foram atrasados em uma hora a cada dia, de forma a permitir a coleta de uma amostra composta representativa de um periodo de $24 \mathrm{hs}$. As amostras de, aproximadamente, $500 \mathrm{ml}$ de cada horário foram compostas por vaca e período, sendo imediatamente congeladas.

A coleta de urina dos animais foi realizada do décimo até o décimo quinto dia de cada periodo de coleta. Para evitar a contaminação das fezes com urina, no nono dia foram colocadas sondas de Foley ( $\left.n^{\circ} 24\right)$ na vesícula urinária. Na extremidade distal da sonda, foi conectado um tubo plástico, transparente e flexivel, medindo $2.5 \mathrm{~m}$ de comprimento e $3 / 4 \mathrm{~mm}$ de diâmetro interno. Este tubo permitia o fluxo da urina para um galão plástico de 20 I que 
continha $75 \mathrm{ml}$ de $\mathrm{HCl}$ (50\%) para manter $0 \mathrm{pH}$ da urina abaixo de 4,0. A quantidade de urina excretada de cada vaca foi pesada diariamente as 7:00 h, retirando-se em seguida uma amostra representando $5 \%$ do peso. Tais amostras foram agrupadas por vaca e período, armazenadas em garrafas plásticas devidamente identificadas e congeladas $\left(-20^{\circ} \mathrm{C}\right)$.

\subsection{Processamento e análise das amostras}

As amostras do alimento oferecido, da cana, do farelo de soja, fezes e conteúdo duodenal foram secas à $60^{\circ} \mathrm{C}$ em estufa de circulação forçada de ar por pelo menos 48 horas. Em seguida, foram moidas em moinho tipo Willey com peneira de malha de $1,0 \mathrm{~mm}$ de diâmetro e acondicionadas em sacos plásticos devidamente identificados.

A matéria seca das dietas oferecidas, da cana, do farelo de soja, das fezes e do conteúdo duodenal foi determinada colocando-se as amostras em estufas a $110^{\circ} \mathrm{C}$ por pelo menos 12 horas. Posteriormente, essas amostras foram colocadas em mufla a $600^{\circ} \mathrm{C}$ por pelo menos três horas para determinação da matéria orgânica e matéria mineral (MM).

A determinação do teor de proteína bruta das amostras das dietas oferecidas, dos ingredientes, conteúdo duodenal e das fezes foi feita através da determinação do nitrogênio total pelo método Micro-Kjeldahl. Nas amostras de urina foi determinado o nitrogênio total pelo método Macro-Kjeldhal, ambos segundo a AOAC (1985).

As determinações de FDN, FDA e lignina foram realizadas de acordo com os métodos descritos por Goering \& Van Soest (1970).

Nas amostras do alimento oferecido e nas fezes foi determinado a concentração de energia bruta (EB) através da oxidação completa em bomba 
calorimétrica Parr ${ }^{\circledR}$, modelo 1261. Nas amostras das fezes e do conteúdo duodenal foram determinados, também, a concentração de cromo pelo método descrito por Pereira e Rossi Jr. (1994).

\subsection{Análise estatística}

A análise de variância foi executada pelo procedimento de Modelos Lineares Gerais ("PROC GLM") do pacote estatístico SAS (1985) para o delineamento experimental quadrado latino.

Tabela 3. Análise de variância para o ensaio de digestibilidade e balanço de nitrogênio.

\begin{tabular}{lc}
\hline Causa da Variação & GL \\
\hline Periodo & $(\mathrm{i}-1)=3$ \\
Vacas & $(\mathrm{j}-1)=3$ \\
Tratamentos & $(\mathrm{k}-1)=3$ \\
Residuo & $(4-1)(4-2)=6$ \\
Total & $4^{2}-1=15$
\end{tabular}

GL = graus de liberdade

A comparação entre as médias dos tratamentos para as diversas variáveis analisadas foi feita através do teste de Tukey, empregando-se 10\% como nível de significância. Para tendências foi considerado o nível de significância de 15\%. O modelo matemático adotado foi:

$$
Y_{i j k}=\mu+P_{i}+V_{J}+t_{k}+\varepsilon_{I J K} ; \operatorname{com} i=j=k=1
$$


onde: $Y_{i j k}=$ valor obsenado correspondente ao k-ésimo tratamento. no i-ésimo período com a j-ésima vaca;

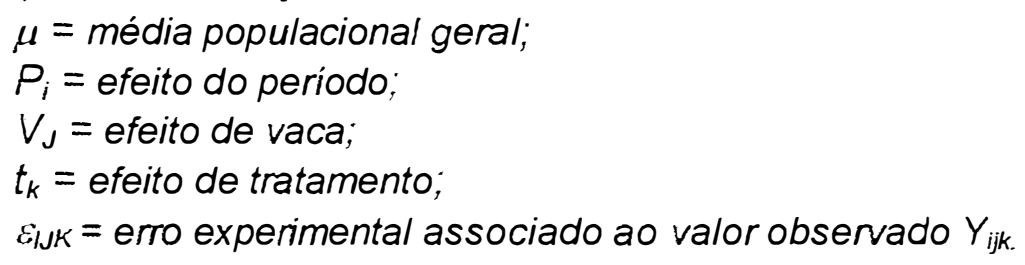




\section{RESULTADOS E DISCUSSÃO}

\subsection{Graus Brix e composição química da cana-de-açúcar}

$\mathrm{Na}$ Tabela 4 são apresentados os valores médios da composição química da cana-de-açúcar e do farelo de soja em cada período experimental.

Tabela 4. Composição química da cana-de-açúcar e do farelo de soja.

\begin{tabular}{lcccccc}
\hline Item & \multicolumn{3}{c}{ Cana-de-açúcar } & Cana & F. soja \\
\hline & I & II & III & IV & \multicolumn{3}{c}{ Média } \\
\hline MS (\%) & 29,69 & 30,74 & 24,23 & 29,11 & 28,44 & 85,39 \\
MO (\%) & 97,16 & 97,76 & 97,51 & 97,67 & 97,53 & 93,49 \\
MM (\%) & 2,84 & 2,24 & 2,49 & 2,33 & 2,48 & 6,51 \\
PB (\%) & 1,62 & 2,22 & 4,06 & 2,21 & 2,53 & 50,15 \\
FDN (\%) & 48,44 & 44,4 & 58,41 & 49,16 & 50,10 & 13,61 \\
FDA (\%) & 29,63 & 26,41 & 34,96 & 30,26 & 30,32 & 10,81 \\
lignina (\%) & 5,06 & 3,9 & 5,44 & 4,56 & 4,74 & 0,32 \\
EB (Mcal/kg MS) & 4,28 & 4,38 & 4,38 & 4,33 & 4,34 & 4,69 \\
\hline
\end{tabular}

Energia Bruta

Durante o experimento, foram utilizadas mais de uma variedade de cana-de-açúcar, as quais foram colhidas em áreas e épocas diferentes. Verifica-se na Tabela 4 uma grande variação na composição química da cana utilizada no terceiro período em relação às usadas nas demais fases do experimento. Nesse período as plantas apresentavam colmos finos e de 
reduzido tamanho, caracteristicos de plantas com menos de 12 meses de idade. A análise bromatológica dessa cana revelou concentrações mais altas de FDN, FDA e lignina e maior teor de PB em relação aos materiais utilizados nos outros periodos. Foi durante esse fase, também, que se observou o menor consumo de MS em todos os tratamentos, o que pode ser atribuido à menor digestibilidade da MS e, possivelmente, maior quantidade de FDN nas dietas nessa fase do experimento.

Essa observação é coerente com vários relatos da literatura, que reportaram redução no teor de PB e componentes fibrosos e, aumento na concentração de sacarose, com o avanço na idade de corte da cana-de-açúcar. Uma das primeiras evidências sobre esse comportamento da cana-de-açúcar foi relatada por Banda \& Valdez (1976) que verificaram mais alta digestibilidade in vitro da MS e mais baixos teores de fibra e PB na cana colhida com 16 meses em relação à cana colhida com 8 meses. Pate (1977) verificou a mesma tendência (Figura 1).

Os teores médios de PB, FDN, FDA apresentados na Tabela 4 são semelhantes aos teores verificados por Pate (1981), que reportou valores médios de $3,4 \%$ para $\mathrm{PB}, 47,0 \%$ para FDN, $29,5 \%$ para FDA em duas variedades de cana. $O$ teor de lignina de $6,3 \%$ relatado por este pesquisador foi, entretanto, superior ao observado nesta pesquisa. Ludovico (1993) verificou teores médios de PB, FDN e FDA na cana-de-açúcar de 1,61\%, $48,2 \%$ e $31,8 \%$, respectivamente.

$\mathrm{Na}$ Tabela 5 são apresentados os teores de uréia que seriam, teoricamente, mais adequados para as dietas com cana-de-açúcar utilizadas nesta pesquisa, considerando-se a fórmula proposta por Ferreiro et al. (1977c) e os valores de graus Brix da cana observados em cada periodo experimental. Aplicando-se a fórmula, verifica-se que o teor de uréia adequado para as dietas 
experimentais seria de $12,09 \mathrm{~g} / \mathrm{kg}$ de cana fresca, ou $1,21 \%$ do peso da cana fresca.

Os valores para os graus Brix do suco da cana não apresentaram grande variação durante os quatro períodos do experimento. Todas as variedades utilizadas destinavam-se para fins industriais, o que explica os valores relativamente elevados para graus Brix dessas variedades.

Ferreiro et al. (1977c) observaram valores de 9,5 a $21,6^{\circ}$ Brix no suco da cana, com os valores mais baixos sendo registrados nas épocas mais chuvosas do ano. Esses pesquisadores detectaram uma correlação significativa $\left(r^{2}=-0,40\right)$ entre os graus Brix do suco da cana e a precipitação do mês anterior. Segundo os dados coletados pelo Núcleo Regional de Monitoramento Agroclimático da ESALQ (NuRMA), no mês de novembro, as chuvas intensificaram-se em Piracicaba (Figura 2), o que pode justificar, portanto, o mais baixo valor para os graus Brix do suco da cana verificado no último período experimental.

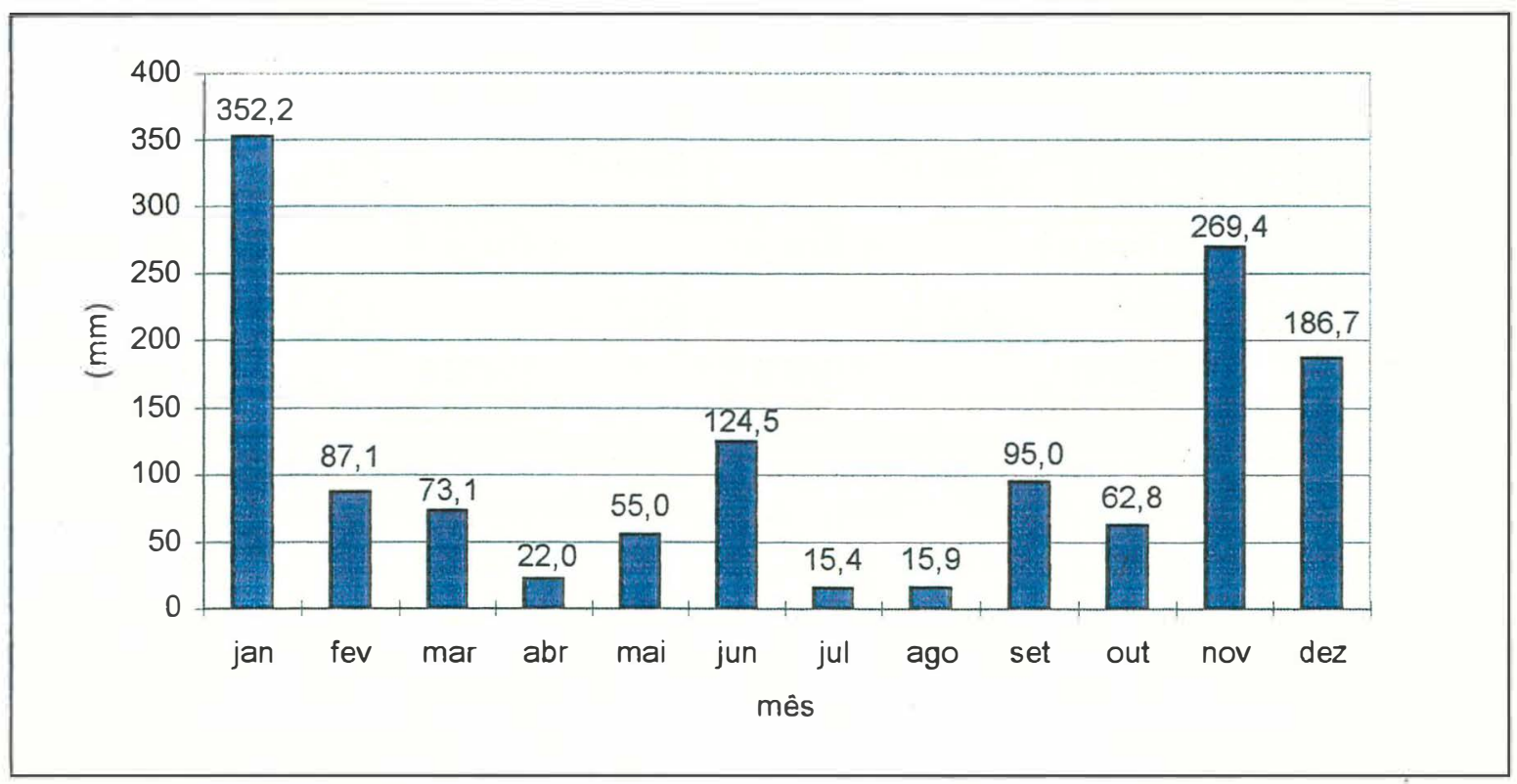

Figura 2. Precipitação mensal no município de Piracicaba em 1997. 
Contudo, não se observou neste experimento a alta correlação entre graus Brix e MS da cana verificada na pesquisa de Ferreiro et al. (1977c). A cana utilizada no terceiro periodo do experimento apresentou o segundo maior valor para graus Brix (Tabela 5) no suco e o menor valor para MS (Tabela 4).

Tabela 5. Teores de uréia calculados para os periodos experimentais de acordo com os graus Brix do suco da cana.

\begin{tabular}{ccc}
\hline Periodo & ${ }^{\circ}$ Brix do suco & Teor de uréia $^{1}$ \\
\hline I & 22,8 & 12,28 \\
II & 23,1 & 12,43 \\
III & 22,9 & 12,33 \\
IV & 20,9 & 11,32 \\
Média & 22,43 & 12,09
\end{tabular}
${ }^{1}$ Teor de uréia ( $\mathrm{g} / \mathrm{kg}$ de cana fresca) $=\frac{0,6 x^{\circ} \mathrm{Brix} x\left(94,81-1,12 x^{\circ} \mathrm{Brix}\right)}{100-{ }^{\circ} \mathrm{Brix}}$

\section{2 Análise bromatológica das dietas experimentais}

Os resultados das análises bromatológicas das dietas experimentais são mostrados na Tabela 6 . Verifica-se que as dietas dos tratamentos $A$ e $B$ apresentaram teores de PB equivalentes, porém um pouco abaixo dos $12 \%$ como havia sido planejado. A dieta do tratamento $A$ apresentou teores mais baixos de FDN, FDA e lignina em função do farelo de soja apresentar baixas concentrações dessas frações fibrosas. As concentrações de energia bruta também foram maiores para a dieta do tratamento $A$, uma vez que o farelo de soja apresenta teores de extrato etéreo superiores em relação à cana-deaçúcar. 
Tabela 6. Composição bromatológica das dietas experimentais.

\begin{tabular}{lcccc}
\hline Item & \multicolumn{4}{c}{ Tratamento } \\
\hline & $\mathrm{A}$ & $\mathrm{B}$ & $\mathrm{C}$ & $\mathrm{D}$ \\
\hline MS (\%) & 31,82 & 27,18 & 26,94 & 26,44 \\
MO (\%) & 96,70 & 97,43 & 97,47 & 97,38 \\
MM (\%) & 3,30 & 2,58 & 2,53 & 2,62 \\
PB (\%) & 11,62 & 11,42 & 15,85 & 19,82 \\
FDN (\%) & 45,77 & 51,51 & 50,16 & 50,10 \\
FDA (\%) & 27,95 & 31,41 & 30,33 & 30,18 \\
Lignina \% & 4,17 & 4,81 & 4,51 & 4,56 \\
EB (Mcal/kg MS) & 4,41 & 4,28 & 4,25 & 4,22 \\
\hline
\end{tabular}

valores médios para os quatro periodos experimentais

\subsection{Consumo e digestibilidade aparente no trato total da matéria seca}

Os valores de consumo e digestibilidade aparente da matéria seca no trato total encontram-se na Tabela 7. Os resultados de consumo de matéria seca devem ser observados com cuidado em função do pequeno número de animais. Os valores para consumo de MS verificados para todos tratamentos são muito baixos, com um valor médio para todos os períodos de $5,31 \mathrm{~kg}$ de $\mathrm{MS} / \mathrm{vaca} /$ dia ou o equivalente a $0,91 \%$ do peso vivo (PV). A média do consumo de MS observado para os tratamentos B, C e D foi de $0,78 \%$ do PV. Ferreiro et al. (1977b) trabalharam com bovinos de corte consumindo dietas à base de cana e uréia e reportaram valores de 1,0 a $1,13 \%$ do PV. O consumo de matéria seca observado para o tratamento $A$ foi de $1,32 \%$ do $P V$, inferior aos obtidos por Ludovico (1993). Esse pesquisador trabalhou com vacas leiteiras alimentadas com dietas à base de cana, uréia e diferentes proporções de farelo 
e semente de algodão ( $12 \%$ de PB nas dietas) e relatou consumos de MS da ordem de 1,44 a $2,10 \%$ do PV.

Verifica-se na Tabela 7 que o consumo de matéria seca observado para o tratamento A foi significativamente superior aos observados para os demais tratamentos. Quando expresso como porcentagem do peso vivo, o consumo de matéria seca no tratamento $A$ também foi maior que nos dos demais tratamentos.

Tabela 7. Consumo e digestibilidade aparente da matéria seca no trato total.

\begin{tabular}{|c|c|c|c|c|c|}
\hline \multirow[t]{2}{*}{ Item } & \multicolumn{4}{|c|}{ Tratamentos } & \multirow[t]{2}{*}{$\overline{\mathrm{epm}}$} \\
\hline & A & $B$ & C & $D$ & \\
\hline \multicolumn{6}{|c|}{ Consumo MS } \\
\hline (kg/dia) & $7,76^{a}$ & $4,94^{b}$ & $4,53^{b}$ & $4,02^{b}$ & 0,469 \\
\hline (\% do PV) & $1,32^{a}$ & $0,86^{b}$ & $0,78^{b}$ & $0,69^{b}$ & 0,089 \\
\hline \multicolumn{6}{|c|}{ Digestibilidade MS } \\
\hline (\% ingerido) & $69,91^{a}$ & $65,10^{c}$ & $69,32^{\mathrm{ab}}$ & $65,37^{b c}$ & 1,022 \\
\hline (kg/dia) & $5,44^{a}$ & $3,29^{b}$ & $3,15^{b}$ & $2,64^{b}$ & 0,350 \\
\hline
\end{tabular}

${ }^{1}$ Erro padrão da média.

Médias seguidas por letras distintas, na mesma linha, diferem entre si $(P<0,10)$ pelo teste de Tukey.

Não se observaram diferenças na ingestão de MS entre os tratamentos em função do teor de proteina bruta das dietas. As dietas dos tratamentos $\mathrm{C} \mathrm{e}$ D, com teores mais elevados de proteina bruta (15,85 e 19,82\% de PB), não apresentaram diferenças significativas para consumo de matéria seca em relação à dieta do tratamento $B(11,42 \%$ de $P B)$. Essa observação não deve ser interpretada como ausência de respostas na ingestão de matéria seca em função do aumento no teor de PB da dieta, mas como ausência de resposta em função do aumento no teor de uréia da dieta. Nota-se, inclusive, uma tendência 
de redução no consumo de MS em função do aumento no teor de uréia da dieta. O tratamento A, cuja dieta apresentou $11,62 \%$ de $\mathrm{PB}$, proporcionou maior consumo de matéria seca que os demais tratamentos que incluíram uréia, sugerindo que a fonte foi mais importante que o teor de proteína com relação ao consumo de matéria seca.

Os menores consumos de matéria seca observados nos tratamentos $B$, $C$ e $D$ podem ter sido uma resposta à baixa palatabilidade da uréia que foi incluída nessas dietas. Huber \& kung Jr. (1981) e Boin (1984) reportaram experimentos em que o fornecimento de uréia reduziu o consumo de matéria seca. Apesar de não existir evidências para concluir que foi a adição de uréia que afetou negativamente o consumo de matéria seca das dietas dos tratamentos $B, C$ e D, torna-se necessário salientar que as vacas apresentaram um apetite muito mais voraz, quando recebiam a dieta com o farelo de soja.

$O$ alto teor de umidade das dietas experimentais também pode ter contribuído para a baixa ingestão de matéria seca verificada para todos os tratamentos. De acordo com o NRC (1989), pode ocorrer uma redução na ingestão de matéria seca da ordem de $0,02 \mathrm{~kg}$ de MS/100 kg de peso vivo, em função do aumento de cada unidade percentual de umidade acima do teor de $50 \%$. Embora este efeito seja mais pronunciado em dietas com silagem e alimentos fermentados do que com outros tipos de forragem, observa-se que os menores consumos de MS ocorreram nos tratamentos com maior teor de umidade (Tabela 6).

Algumas pesquisas têm mostrado aumento na ingestão de matéria seca nas dietas à base de cana-de-açúcar em função do aumento no teor de uréia. No entanto, esse efeito parece ser mediado pela presença de outros alimentos na dieta. 
Alvarez \& Preston (1976) verificaram aumento no consumo de MS de 2,0 para $2,67 \%$ do $\mathrm{PV}$, quando o teor de uréia nas dietas com cana foi aumentado de zero para $1,5 \%$ do peso fresco da cana. No entanto, os animais foram suplementados com 1,0 kg/dia de polidura de arroz.

Preston et al. (1976) trabalharam com dietas de cana, utilizando um teor fixo de uréia e várias quantidades de polidura de arroz na dieta dos animais. No tratamento em que os animais receberam $1,2 \mathrm{~kg} / \mathrm{dia}$ de polidura de arroz, o consumo de MS foi de $6,63 \mathrm{~kg} / \mathrm{dia}$. No tratamento em que foi fornecido 0,3 $\mathrm{kg} /$ dia de polidura de arroz, o consumo de $\mathrm{MS}$ foi de $4,37 \mathrm{~kg} / \mathrm{dia}$. Isso corresponde a uma diferença na ingestão de MS de 52\%, aproximadamente. No tratamento em que foi fornecido $0,3 \mathrm{~kg} /$ dia de polidura de arroz, a uréia representou cerca de $84 \%$ da PB da dieta, enquanto que no tratamento que incluia $1,2 \mathrm{~kg} / \mathrm{dia}$ de polidura de arroz, a uréia contribui com apenas $69 \%$ da PB da dieta.

Ferreiro et al. (1977b) não verificaram diferenças significativas para o consumo de MS em dietas à base de cana-de-açúcar em função de diferentes teores de uréia. O consumo de MS variou de 1,0 a 1,13\% do peso vivo em animais recebendo de 0 a $1,6 \%$ de uréia para cada $\mathrm{kg}$ de cana fresca. Nesse experimento, não houve suplementação dos animais com polidura de arroz.

Com relação à digestibilidade aparente da MS no trato total, verificou-se que o tratamento $A(69,91 \%)$ foi superior aos tratamentos $B(65,10 \%)$ e $D$ (65,37\%), mas não apresentou diferença em comparação com o tratamento $C$ $(69,32 \%)$. Os coeficientes de digestibilidade aparente da MS no trato total obtidos nesta pesquisa são bastante próximos aos existentes na literatura (Tabela 1). Comparando-se os tratamentos que incluíram uréia na dieta ( $\mathrm{B}, \mathrm{C}$ e D), verificou-se que o coeficiente de digestibilidade da MS no trato total da dieta do tratamento $C$ foi superior em relação ao do tratamento $B$ e tendeu a 
ser superior ao do tratamento D. Esses resultados diferem daqueles obtidos por Ferreiro et al. (1977b) e Rodriguez et al. (1993), que não encontraram diferenças significativas para a digestibilidade da matéria seca no trato total entre os tratamentos com diferentes teores de uréia. Na pesquisa desenvolvida por Ferreiro et al. (1977b) foram utilizados apenas os colmos e não a cana-deaçúcar integral como volumoso. No trabalho realizado por Rodriguez et al. (1993), apesar do volumoso ter sido a cana-de-açúcar integral, as dietas também continham farelo de algodão.

De acordo com o NRC (1989), em dietas com baixa concentração energética, o resíduo indigestível da dieta pode ser o principal fator regulando o consumo de matéria seca, envolvendo mecanismos de "enchimento" e distensão do trato digestivo. Desta forma, à medida que a digestibilidade da MS da dieta é elevada, ocorre aumento proporcional na ingestão de MS. Esse efeito é observado até a digestibilidade atingir valores de $67 \%$. A partir desse ponto, que não deve ser fixo para todas as dietas, o consumo passaria a ser regulado por mecanismos químicos.

Neste experimento, a digestibilidade da MS no trato total da dieta do tratamento $A$ foi superior às das dietas dos tratamentos $B$ e $D$, o que poderia explicar o maior consumo de MS observado para o tratamento com farelo de soja. No entanto, não se verificaram diferenças na digestibilidade da MS entre os tratamentos A e C, embora o consumo de MS tenha sido maior no tratamento $\mathrm{A}$.

A quantidade de MS digerida no trato total foi maior para o tratamento $A$ em relação aos demais tratamentos, o que deve ser explicado pelo maior consumo de MS observado neste tratamento. Não foram verificadas diferenças na quantidade de matéria seca digerida entre os três tratamentos que incluíram uréia. 


\subsection{Consumo e digestibilidade aparente no trato total das diversas frações das dietas experimentais}

O consumo das diversas frações das dietas e os respectivos coeficientes de digestibilidade aparente no trato total são apresentados na Tabela 8. A digestibilidade dos nutrientes é expressa tanto em ( $\mathrm{kg} / \mathrm{dia})$, quanto em porcentagem (\%) do nutriente ingerido.

Observa-se na Tabela 8 que o consumo de matéria orgânica seguiu o mesmo padrão verificado para o consumo de matéria seca. Isso era esperado, já que as dietas dos tratamentos não apresentaram grandes diferenças em termos de matéria mineral. O consumo de $\mathrm{MO}$ no tratamento $\mathrm{A}$ foi maior que os observados para os demais tratamentos, refletindo o consumo de MS observado para esse tratamento.

A digestibilidade da $\mathrm{MO}$ no trato total também seguiu a mesma tendência observada para a digestibilidade da MS. A dieta do tratamento $C$ apresentou maior digestibilidade da $\mathrm{MO}$ do que as dietas dos tratamentos $\mathrm{B}$ e D. A digestibilidade aparente da $\mathrm{MO}$ no trato total da dieta do tratamento $\mathrm{A}$ foi superior à dieta do tratamento $B(72,71$ vs $68.75 \%)$, mas não foi superior às dietas dos tratamentos C $(73,00 \%)$ e D $(69,21 \%)$.

A quantidade de matéria orgânica digerida seguiu o mesmo padrão observado para a quantidade de MS digerida. $O$ tratamento $A$ apresentou maior quantidade de MO digerida em relação aos demais tratamentos, como conseqüência do maior consumo de MS. Não se notaram diferenças entre os tratamentos B, C e D. Apesar da digestibilidade da $\mathrm{MO}$ em porcentagem do ingerido ter sido mais elevada para o tratamento $C$ em relação ao tratamento $B$, o consumo de MS numericamente mais alto verificado no tratamento B compensou a menor digestibilidade. 
Tabela 8. Consumo e digestibilidade aparente das frações das dietas no trato total.

\begin{tabular}{|c|c|c|c|c|c|}
\hline \multirow[t]{2}{*}{ Item } & \multicolumn{4}{|c|}{ Tratamento } & \multirow[t]{2}{*}{ epm ${ }^{1}$} \\
\hline & $A$ & $B$ & $\mathrm{C}$ & $\mathrm{D}$ & \\
\hline \multicolumn{6}{|l|}{ MO } \\
\hline Consumo (Kg/dia) & $7,50^{a}$ & $4,82^{b}$ & $4,42^{b}$ & $3,92^{b}$ & 0,456 \\
\hline $\operatorname{DATT}(\%)^{2}$ & $72,21^{\mathrm{ab}}$ & $68,75^{\mathrm{c}}$ & $73,00^{a}$ & $69,21^{b c}$ & 0,811 \\
\hline DATT (kg/dia) & $5,43^{a}$ & $3.37^{b}$ & $3,23^{b}$ & $2,72^{b}$ & 0,340 \\
\hline \multicolumn{6}{|l|}{ PB } \\
\hline Consumo (Kg/dia) & $0,896^{a}$ & $0,549^{b}$ & $0,715^{a b}$ & $0,795^{a b}$ & 0,076 \\
\hline DATT (\%) & $72,13^{b}$ & $73,97^{b}$ & $83,81^{a}$ & $85,23^{a}$ & 1,341 \\
\hline DATT (kg/dia) & $0,650^{a b}$ & $0,411^{b}$ & $0,599^{a b}$ & $0,678^{a}$ & 0,064 \\
\hline \multicolumn{6}{|l|}{ FDN } \\
\hline Consumo (Kg/dia) & $3,56^{a}$ & $2,45^{b}$ & $2,25^{b}$ & $2,00^{b}$ & 0,217 \\
\hline DATT (\%) & $55,42^{a}$ & $54,30^{a}$ & $59,56^{a}$ & $54,73^{a}$ & 1,493 \\
\hline DATT (kg/dia) & $2,01^{a}$ & $1,34^{b}$ & $1,34^{b}$ & $1,10^{b}$ & 0,130 \\
\hline \multicolumn{6}{|l|}{ FDA } \\
\hline Consumo (Kg/dia) & $2,17^{a}$ & $1,50^{b}$ & $1,37^{b}$ & $1,20^{b}$ & 0,130 \\
\hline DATT (\%) & $55.48^{a b}$ & $54,66^{b}$ & $59,16^{a}$ & $53,52^{b}$ & 0,959 \\
\hline DATT (kg/dia) & $1,22^{a}$ & $0,82^{b}$ & $0,81^{b}$ & $0,65^{b}$ & 0,074 \\
\hline \multicolumn{6}{|l|}{ EB } \\
\hline Consumo (Mcal/dia) & $34,19^{a}$ & $21,12^{b}$ & $19,27^{b}$ & $16,97^{b}$ & 2,058 \\
\hline DATT (\%) & $69,83^{a}$ & $64,75^{b}$ & $69,34^{a}$ & $65,14^{b}$ & 0,971 \\
\hline
\end{tabular}

'Erro padrão da média.

${ }^{2}$ DATT = digestibilidade aparente no trato total

Média seguidas de letras distintas na mesma linha diferem entre si $(P<0,10)$ pelo teste de Tukey.

O consumo de proteína bruta no tratamento $B$ foi menor que no tratamento $A$, mas não foi diferente dos tratamentos $C$ e $D$. Apesar das dietas 
dos tratamentos $C$ e D apresentarem maiores teores de PB do que a dieta do tratamento $A$, o maior consumo de matéria seca observado para esse tratamento anulou esse efeito.

A digestibilidade aparente da PB no trato total das dietas dos tratamentos $C$ e $D$ foram superiores às das dietas dos tratamentos $A$ e $B$. Isso aconteceu, provavelmente, porque nos tratamentos C e D a fração nitrogenada das dietas era constituida praticamente apenas por NNP proveniente da uréia. Como esse nitrogênio é imediatamente solubilizado e absorvido, muito pouco dessa proteina dietética é perdida nas fezes. Nos tratamentos A e B, uma maior proporção da PB dietética deveria ser constituída por proteinas de menor degradabilidade, seja da cana ou do farelo de soja, resultando em maiores perdas de proteína dietética nas fezes.

O menor coeficiente de digestibilidade aparente da PB observado nos tratamentos A e B pode ter sido influenciado, também, pelo maior consumo de MS. Consumos de MS elevados estão associados a maior quantidade de nitrogênio metabólico fecal (perdas endógenas de nitrogênio e, principalmente resíduos indigeridos de proteína microbiana). O NRC (1985) estabeleceu essa perda de nitrogênio como equivalente a $30 \mathrm{~g}$ de PB/kg de MS ingerida.

Aroeira et al. (1993a) verificaram coeficientes de digestibilidade aparente da proteina bruta no trato total de 75,2 e 65,7\% para dietas com cana, uréia e farelo de algodão e de arroz, respectivamente. O coeficiente de digestibilidade aparente da PB no trato total observado para o tratamento $A$ $(72,13 \%)$ situa-se entre esses valores.

O reduzido consumo de MS é, conforme já salientado, uma das principais limitações das dietas com cana-de-açucar e tem sido associado à quantidade e à digestibilidade da fibra (FDN) dessas dietas. 
O consumo de FDN observado no presente trabalho foi maior para o tratamento $A$, cuja concentração de FDN na dieta era menor do que a observada nos demais tratamentos. Isso aconteceu, porque o consumo de MS para esse tratamento foi bastante superior aos dos demais tratamentos. Apesar de existir alta correlação entre às propriedades de enchimento do alimento e essa fração da dieta (Dado \& Allen, 1995), a quantidade de FDN consumida no tratamento $A$ foi maior que a quantidade de FDN consumida nos demais tratamentos, sugerindo que os animais foram capazes, durante este tratamento, de se adaptar a um maior volume e massa de fibra. Isso pode ter ocorrido através de maior expansão do volume ruminal, ou através de aumento na taxa de passagem. Não foram observadas, porém, diferenças entre os demais tratamentos $(B, C$ e $D)$ em relação ao consumo de FDN.

Pate (1981) trabalhou com dietas com diferentes proporções de silagem de milho e cana-de-açúcar. Esse pesquisador relatou que, a quantidade de FDN não deveria ser o fator responsável pelo baixo consumo observado nas dietas com maior proporção de cana, uma vez que o teor de FDN dessas dietas não foi muito diferente do teor de FDN das dietas com mais silagem de milho.

Allen (1996) afirmou que há várias evidências de que o FDN sozinho deve ser inadequado para prever os efeitos de "enchimento" das forragens. Segundo esse pesquisador, diferenças no tamanho inicial e fragilidade das partículas, taxa de digestão da FDN, capacidade de retenção de gases, densidade das partículas e estágio de lactação do animal podem interferir no efeito de "enchimento" do trato digestivo afetando o consumo de matéria seca dos animais.

O modelo desenvolvido por Mertens (1987) previa que vacas poderiam consumir aproximadamente $1,2 \%$ do PV em FDN. Verifica-se na Tabela 7 que nem o consumo de MS atingiu essa magnitude nos tratamentos com cana e 
uréia (B, C e D). Entretanto: Aroeira et al. (1995) reportou consumo de FDN da ordem de $1,6 \%$ do peso vivo, com vacas mestiças em lactação, alimentadas com cana, uréia, farelo de algodão e concentrado.

Os coeficientes de digestibilidade da FDN no trato total observados neste trabalho $(54,3$ a $59,6 \%)$ foram superiores aos reportados, freqüentemente, na literatura. Aroeira et al. (1993a) relataram coeficientes de digestibilidade aparente da FDN no trato total de 39,7 e 35,8\% em novilhos consumindo dietas à base de cana, uréia ( $1 \%$ do peso fresco da cana) e farelo de algodão e arroz, respectivamente. Essa diferença pode ser justificada, pelo menos em parte, pelo reduzido consumo de MS observado neste experimento. Na pesquisa conduzida por Aroeira et al. (1993a), o consumo de MS reportado foi de 1,6 a 2,0\% do peso vivo. Aroeira et al. (1993b) avaliaram as alterações na cinética ruminal no mesmo experimento e reportaram taxas de passagens da cana-de-açúcar no rúmen de 3,1 e $3,2 \% / h$, as quais os autores consideraram elevadas para animais alimentados em nivel de mantença. Essa maior ingestão de MS poderia ocasionar uma maior taxa de passagem da digesta, com conseqüente redução na digestibilidade da fração fibrosa no trato total.

Não se observaram, neste trabalho, diferenças na digestibilidade aparente da FDN no trato total entre os tratamentos. Aroeira et al. (1993c) observaram tendência de aumento na taxa de degradação da FDN da cana no rúmen de bovinos alimentados com dietas com cana, uréia e farelo de algodão nos tratamentos que incluíram níveis mais elevados de uréia $(1,5$ e 2,0\% do peso da cana fresca). No mesmo experimento, Figueira et al. (1993) reportaram menor tempo de retenção da cana-de-açúcar no rúmen para o tratamento que incluía $1,5 \%$ de uréia (sobre o peso da cana fresca). 
Apesar de não ter sido notado, nessa pesquisa, maior digestibilidade da FDN na dieta do tratamento $A$, o que poderia explicar o maior consumo, não se pode descartar a hipótese de que fontes de proteína verdadeira disponiveis para os microrganismos ruminais poderiam aumentar as taxas de digestão ruminal da fração fibrosa. Isso poderia ocorrer, provavelmente, por essa fonte de proteína melhor atender às exigências das bactérias ruminais, através do suprimento de ácidos graxos de cadeia ramificada, peptídeos e aminoácidos (Russel et al. 1992 e Van Soest, 1994). Maiores taxas de digestão ocasionariam, segundo Allen (1996), menor tempo de retenção das partículas no complexo retículo-rúmen (menor tempo flutuando), permitindo às partículas deixarem esse compartimento mais rapidamente. $O$ coeficiente de digestibilidade aparente da FDN no trato total não precisaria ser necessariamente alterado, uma vez que o menor tempo de residência no rúmen reduziria a extensão da digestão nesse órgão.

Com relação a FDA, observa-se que, da mesma forma que ocorreu com as demais frações das dietas, o consumo de FDA foi maior para o tratamento A, refletindo o maior consumo de MS verificado nesse tratamento. A dieta do tratamento $C$ apresentou maior digestibilidade da FDA no trato total do que as dietas dos tratamentos $\mathrm{B}$ e $\mathrm{D}$. Contudo, não se observaram diferenças em relação a digestibilidade aparente da FDA no trato total entre os tratamentos $A$, $B$ e $D$ e entre $A$, e $C$.

A digestibilidade aparente da FDA no trato total variou de 53,52 a $59,16 \%$ entre os tratamentos utilizados na presente pesquisa. Esses valores são superiores aos reportados por Rodriguez et al. (1993) e por Aroeira et al. (1993a), que observaram coeficientes de digestibilidade aparente da FDA no trato total da ordem de 34,57 e $33,45 \%$, respectivamente. Diferenças no consumo de MS poderiam explicar essas diferenças. 
Rodriguez et al. (1993) verificaram tendência linear de aumento na digestibilidade aparente da FDA em função do aumento no teor de uréia em dietas com cana e farelo de algodão, com maior digestibilidade da FDA para o tratamento com $2,0 \%$ de uréia. No entanto neste trabalho, observou-se que a concentração de $1,5 \%$ de uréia (tratamento $C$ ) foi superior em relação à concentração de $2,0 \%$ de uréia.

A dieta do tratamento $A$ apresentou maior concentração de energia bruta do que as dietas dos demais tratamentos, possivelmente pelo maior teor de extrato etéreo contido no farelo de soja. O consumo de energia bruta (EB) foi, logicamente, significativamente superior para o tratamento $A$, que também já havia apresentado maior consumo de MS.

A digestibilidade aparente da EB no trato total das dietas dos tratamentos com farelo de soja (A) e com 1,5\% de uréia (C) foram superiores àquelas com $1,0 \%$ de uréia (B) e $2,0 \%$ de uréia (D). Não se verificaram diferenças na digestibilidade aparente da EB no trato total entre os tratamentos $A$ e $C$ e entre $B$ e $D$.

A concentração e o consumo de energia digestivel (ED) observados para cada tratamento são apresentados na Tabela 9 , juntamente com as exigências diárias de energia digestivel para vacas secas e não gestantes extraídas do NRC (1989). A concentração de ED nas dietas do tratamento $A e$ $C$ foram superiores às dos tratamentos $B$ e $D$, refletindo os maiores coeficientes de digestibilidade da energia bruta verificados para os tratamentos $A$ e $C$. O consumo de energia digestivel observado para 0 tratamento $A$ foi maior em relação aos demais tratamentos.

Observa-se que o consumo de energia digestivel no tratamento $A$ foi de aproximadamente $24,0 \mathrm{Mcal}$ de ED/dia, enquanto nos demais tratamentos, o 
consumo de energia foi da ordem de 11,0 a 14,0 Mcal ED/dia, não sendo observado diferenças significativas entre eles.

Tabela 9. Concentração e consumo de energia digestivel.

\begin{tabular}{lccccc}
\hline Item & \multicolumn{4}{c}{ Tratamento } & epm $^{+}$ \\
\hline & $\mathrm{A}$ & $\mathrm{B}$ & $\mathrm{C}$ & $\mathrm{D}$ & \\
\hline ED (Mcal/kg MS) & $3,08^{\mathrm{a}}$ & $2,77^{\mathrm{b}}$ & $2,95^{\mathrm{a}}$ & $2,75^{\mathrm{b}}$ & 0,041 \\
Consumo ED (Mcal/dia) & $23,91^{\mathrm{a}}$ & $13,97^{\mathrm{b}}$ & $13,38^{\mathrm{b}}$ & $11,09^{\mathrm{b}}$ & 1,500 \\
Exigências ED (Mcal/dia) $^{2}$ & 18,71 & 18,71 & 18,71 & 18,71 & - \\
Balanço energético (Mcal/dia) $^{2}$ & $5,2^{2}$ & $-4,74$ & $-5,33$ & $-7,62$ & - \\
\hline
\end{tabular}

'Erro padrão da média

${ }^{2}$ Exigências de energia digestível para uma vaca adulta de $600 \mathrm{~kg}$ seca e vazia NRC (1989).

Médias seguidas de letras distintas na mesma linha diferam entre si $(P<0,10)$ pelo teste de Tukey.

As exigências energéticas, expressas em termos de energia digestivel, propostas pelo NRC (1989) são da ordem de 13,8 a $21.0 \mathrm{Mcal} /$ dia para vacas secas, não gestantes e pesando de 400 a $700 \mathrm{~kg}$, respectivamente. Isso demonstra que os tratamentos $B, C$ e $D$ não atenderam a essas exigências, indicando que dietas com cana-de-açúcar suplementadas apenas com uréia podem comprometer o desempenho animal, mesmo para bovinos adultos em mantença, se o consumo de MS for baixo.

\subsection{Digestibilidade ruminal}

Apesar dos animais estarem providos de cânulas duodenais e terem sido coletadas e analisadas amostras do conteúdo duodenal, não foi possível 
estimar os coeficientes de digestibilidade no rúmen através da concentração dos marcadores utilizados nesta pesquisa (óxido de cromo e lignina).

A concentração de lignina e do óxido de cromo no conteúdo duodenal indicaram coeficientes de digestibilidade ruminal muito baixos, ou até mesmo, negativos. Aparentemente, as falhas quanto ao esquema de amostragem devem ter tido pouca influência, uma vez que não se conseguiu a recuperação total dos marcadores também nas fezes, as quais foram coletadas na sua totalidade e bem homogeneizadas.

Uma possivel explicação para o problema observado com o óxido de cromo poderia envolver a grande quantidade de óxido de cromo fornecida para os animais nesta pesquisa (50g/vaca/dia). Os procedimentos de digestão das amostras para determinação da concentração de cromo foram repetidos mais de quatro vezes, como foram repetidas as leituras em espectofotômetro de absorção atômica. Para se confirmar a existência de erros nas leituras causados por falhas na calibração do aparelho do Laboratório de Bromatologia do Departamento de Zootecnia, dois lotes de amostras já digeridas foram encaminhadas para o Setor de Química Analítica - Departamento de Química da ESALQ, onde a determinação da concentração de cromo nas amostras revelou valores semelhantes aos obtidos anteriormente. Para garantir que os niveis de concentração de cromo nas amostras estivessem dentro da faixa de melhor sensibilidade de leitura do espectofotômetro de absorção atômica, as amostras foram diluídas, após a digestão, em água destilada e deionizada, procedimento que melhorou muito pouco os resultados obtidos.

Problemas semelhantes, com estimativa da digestibilidade ruminal através da concentração do óxido de cromo aconteceram em mais três experimentos conduzidos, durante o mesmo período, no Departamento de Zootecnia da ESALQ-USP com vacas holandesas em lactação. Em dois destes 
experimentos, as dietas eram constituídas de silagem de milho e concentrado e no terceiro, de cana-de-açúcar (a mesma utilizada nesta pesquisa) e concentrado. A quantidade de óxido de cromo utilizadas nestes experimentos foi da ordem de $30 \mathrm{~g} / \mathrm{animal} / \mathrm{dia}$, sendo que a ingestão de $\mathrm{MS}$ destes animais foi da ordem de 18,0 kg/dia. Aroeira et al. (1995) utilizaram doses de óxido de cromo de 10g/vaca/dia para estimar digestibilidade aparente da MS no trato total em vacas em lactação consumindo dietas à base de cana-de-açúcar. Os autores reportaram coeficientes de digestibilidade da MS mais elevados que os normalmente reportados na literatura através da coleta total das fezes. De seis experimentos conduzidos por Nussio ${ }^{1}$ na Universidade do Arizona, em três foram observados problemas com determinação dos coeficientes de digestibilidade através do uso de óxido de cromo como marcador.

Os problemas relacionados com a recuperação de lignina são mais freqüentemente relatados na literatura. Segundo Van Soest (1994), embora a lignina seja considerada uma fração indigestivel dos alimentos, forragens imaturas e forragens com baixo teor de lignina têm mostrado digestibilidade aparente da ordem de 20 a 40\%. Este autor reportou inúmeros fatores que podem explicar as falhas na recuperação total da lignina, como contaminação da lignina bruta com outras frações do alimento, perda de lignina imatura, formações de compostos fenólicos solúveis, pequena recuperação de lignina finamente dividida nas fezes e superaquecimento das amostras no momento da secagem. Este autor relata também que a lignina deve ser um excelente marcador nos alimentos com mais que $5 \%$ de lignina na MS.

Nesta pesquisa, a recuperação da lignina nas fezes foi da ordem de $88,55 \%$ para o tratamento $\mathrm{D}, 78,45 \%$ para $\circ$ tratamento $\mathrm{B}, 73,0 \%$ para $\circ$

\footnotetext{
Nussio, L. G. Departamento de Zootecnia da ESALQ-USP - comunicação pessoal, 1998.
} 
tratamento $C$ e $69,68 \%$ para o tratamento $A$. Isso eqüivaleria a um coeficiente médio de digestibilidade aparente da lignina de $24 \%$. Todas as dietas experimentais apresentaram menos que $5 \%$ de lignina na matéria seca. A dieta do tratamento $A$, que apresentou o menor teor de lignina, apresentou o menor coeficiente de recuperação da lignina nas fezes.

\subsection{Balanço de nitrogênio}

Os resultados do ensaio de balanço de nitrogênio são apresentados na Tabela 10 e na Figura 3. Observa-se que a quantidade de nitrogênio consumido ( $\mathrm{g} / \mathrm{dia}$ ) no tratamento $B$ foi menor que no tratamento $A$. Não se observaram diferenças entre os tratamentos $A, C$ e $D$ e entre os tratamentos $B, C$ e $D$ quanto ao consumo de $\mathrm{N}$.

A quantidade de nitrogênio excretado ( $g / d i a)$ foi semelhante nos tratamentos $\mathrm{A}, \mathrm{B}$ e $\mathrm{C}$, mas no tratamento $\mathrm{D}$ (com maior teor de uréia na dieta) ocorreu maior excreção de $\mathrm{N}$ que nos demais tratamentos. Isso deve ter sido ocasionado pela maior excreção urinária de nitrogênio verificada no tratamento D em comparação com os demais tratamentos. Nota-se, na Tabela 10, uma tendência de aumento na excreção de $\mathrm{N}$ via urina em função do aumento no teor de uréia das dietas. $\mathrm{A}$ excreção urinária de $\mathrm{N}$ foi maior no tratamento $\mathrm{D}$ do que nos tratamentos $B$ e $C$. Observou-se maior excreção urinária de $\mathrm{N}$ no tratamento $C$ que no tratamento $B$. A maior excreção urinária de nitrogênio observada no tratamento $D$ em relação aos demais tratamentos, que incluiam uréia, indica que a quantidade de uréia utilizada nesse tratamento foi excessiva em relação à capacidade de utilização ruminal. Com relação ao nitrogênio excretado nas fezes, não se observaram diferenças entre os tratamentos que incluiam uréia nas dietas $(B, C$ e $D)$. No tratamento $A$ ocorreram maiores perdas de $\mathrm{N}$ nas fezes que nos tratamentos $\mathrm{B}, \mathrm{C}$ e $\mathrm{D}$. 
Tabela 10. Consumo de nitrogênio, nitrogênio urinário, nitrogênio fecal, balanço de nitrogênio e nitrogênio retido.

\begin{tabular}{lccccc}
\hline Item & \multicolumn{4}{c}{ Tratamento } & epm \\
\hline & $\mathrm{A}$ & $\mathrm{B}$ & $\mathrm{C}$ & $\mathrm{D}$ & \\
\hline $\mathrm{N}$ (g/dia) & $143,39^{\mathrm{a}}$ & $87,71^{\mathrm{b}}$ & $114,28^{\mathrm{ab}}$ & $127,24^{\mathrm{ab}}$ & 12,06 \\
Nexc (g/dia) & $102,73^{\mathrm{b}}$ & $85,96^{\mathrm{b}}$ & $105,87^{\mathrm{b}}$ & $139,86^{\mathrm{a}}$ & 6,18 \\
Nur (g/dia) & $63,34^{\mathrm{c}}$ & $63,88^{\mathrm{c}}$ & $87,27^{\mathrm{b}}$ & $121,11^{\mathrm{a}}$ & 4,78 \\
Nu (\% excretado) & $61,77^{\mathrm{c}}$ & $74,07^{\mathrm{b}}$ & $82,59^{\mathrm{a}}$ & $86,60^{\mathrm{a}}$ & 2,04 \\
Nfz (g/dia) & $39,39^{\mathrm{a}}$ & $22,08^{\mathrm{b}}$ & $18,60^{\mathrm{b}}$ & $18,75^{\mathrm{b}}$ & 1,27 \\
Nf (\% ecretado) & $38,23^{\mathrm{a}}$ & $25,93^{\mathrm{b}}$ & $17,41^{\mathrm{c}}$ & $13,40^{\mathrm{c}}$ & 1,27 \\
BN (g/dia) & $40,66^{\mathrm{a}}$ & $1,75^{\mathrm{b}}$ & $8,41^{\mathrm{b}}$ & $-12,62^{\mathrm{b}}$ & 7,68 \\
NR (\% do ingerido) & $26,52^{\mathrm{a}}$ & $-0,23^{\mathrm{b}}$ & $6,55^{\mathrm{ab}}$ & $-10,54^{\mathrm{b}}$ & 5,82 \\
\hline
\end{tabular}

'Erro padrão da média

$\mathrm{N}=$ nitrogênio consumido, Nexc = nitrogênio excretado, Nur = nitrogênio excretado via urina, $\mathrm{Nu}=$ nitrogênio excretado via urina como \% do nitrogênio excretado, $\mathrm{Nfz}=$ nitrogênio excretado via fezes, $\mathbf{N f}=$ nitrogênio excretado via fezes como $\%$ do nitrogênio excretado, $\mathrm{BN}=$ balanço de nitrogênio, $\mathrm{NR}=$ nitrogênio retido como $\%$ do nitrogênio consumido.

Médias seguidas de letras distintas na mesma linha diferem entre si $(P<0,10)$ pelo teste de Tukey.

$\mathrm{Na}$ Tabela 10 são apresentados, também, os dados de excreção de nitrogênio nas fezes e na urina como porcentagem do total de nitrogênio excretado. Observou-se que uma maior proporção de $\mathrm{N}$ foi excretada via urina nos tratamentos com teores mais elevados de uréia ( $C$ e $D$ ) do que nos tratamentos $\mathrm{A}$ e $\mathrm{B}$. Uma relação inversa pode ser observada com relação à porcentagem de $\mathrm{N}$ excretado nas fezes. Esses dados confirmam a hipótese formulada anteriormente para explicar as diferenças observadas na digestibilidade da PB no trato total. 
Resultados semelhantes foram obtidos por Araújo et al. (1994), que avaliaram o efeito da degradabilidade ruminal da proteína sobre o balanço de nitrogênio. Utilizando cinco dietas isoprotéicas (24\% de PB), mas com diferentes porcentagens de proteina degradável no rúmen, eles observaram que as dietas com maior porcentagem de proteina degradável no rúmen promoveram as maiores excreções de $\mathrm{N}$ através da urina e as menores excreções de $\mathrm{N}$ através das fezes.

A mesma tendência foi observada por Lavezzo et al. (1996), que avaliaram o efeito da substituição parcial do farelo de soja por uréia em dietas com feno de graminea e concentrado. Esses pesquisadores verificaram que 0 aumento na proporção de uréia na proteína da dieta causou aumento na quantidade de $\mathbf{N}$ excretado via urina e redução na quantidade de $\mathbf{N}$ excretado nas fezes.

Quanto ao balanço de nitrogênio ( $g / d i a)$, verifica-se que o tratamento $A$, que incluia farelo de soja como fonte de proteina, foi superior demais tratamentos. Não se observaram diferenças para o balanço de nitrogênio entre os tratamentos $\mathrm{B}, \mathrm{C}$ e D.

Embora estes valores não apresentem diferenças do ponto de vista estatístico, eles podem assumir significados biológicos bastante distintos. No tratamento $D, \circ$ balanço de nitrogênio foi negativo, indicando que a proteína ingerida não foi capaz de atender às exigências de nitrogênio do animal, o qual precisou mobilizar proteína dos tecidos para poder adequar-se à essa situação de reduzido aproveitamento da proteina dietética. Para o tratamento $\mathrm{B}, \mathrm{O}$ balanço de nitrogênio próximo de zero indicou que 0 animal estava em equilibrio, ou seja, a proteina ingerida foi capaz de atender às suas exigências de nitrogênio. Balanços de nitrogênio positivos verificados nos tratamentos $\mathrm{A} e$ 
C indicam que a proteína ingerida foi adequadamente aproveitada, permitindo retenção de nitrogênio no organismo animal.

Quando o nitrogênio retido foi calculado como porcentagem do nitrogênio ingerido, observou-se a superioridade da dieta do tratamento $\mathrm{A}$ em relação às dietas dos tratamento B e D. Não se observaram, entretanto, diferenças entre os tratamentos $A$ e $C$ e entre $B, C$ e D. É necessário salientar que apenas os tratamentos $A$ e $C$ apresentaram valores positivos.

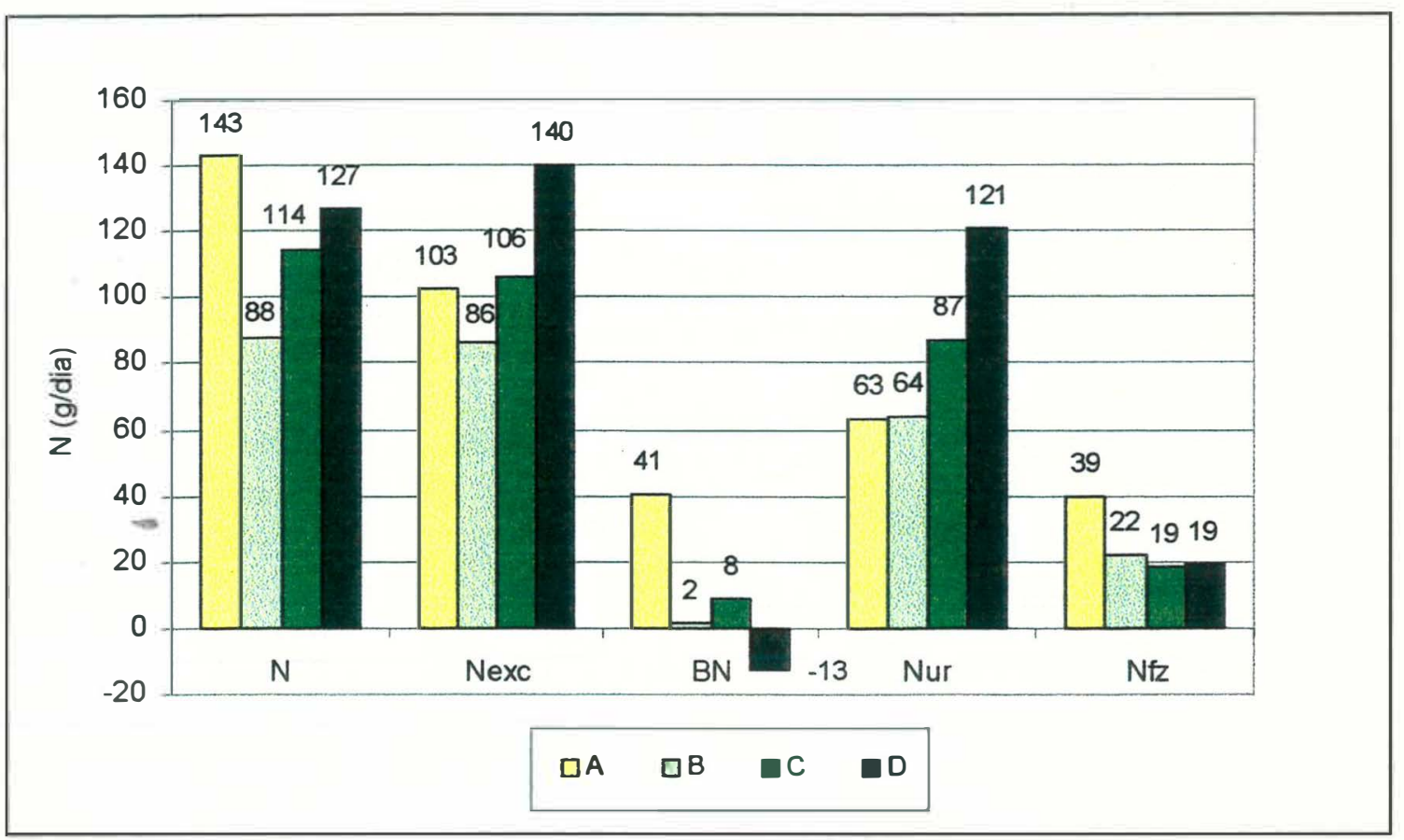

Figura 3. Consumo de nitrogênio, nitrogênio excretado, balanço de nitrogênio, nitrogênio excretado na urina e nitrogênio excretado nas fezes.

Trabalhando com dietas à base de cana, farelo de algodão e três níveis de uréia (1,0; 1,5 e 2,0\% da cana fresca), Rodriguez et al. (1993) verificaram balanços positivos para os três tratamentos, observando efeito linear do teor de uréia sobre o balanço e excreção urinária de nitrogênio. No entanto, os autores 
ressaltaram que, como o aumento no balanço de nitrogênio (630\%) foi superior ao aumento no nitrogênio excretado via urina (85\%), ocorreu um aumento do nitrogênio retido, uma vez que nitrogênio fecal permaneceu constante. Foi detectada superioridade para o tratamento com 2,0\% de uréia em relação aos tratamentos com 1,0 e 1,5\% de uréia. No entanto, nesse tratamento também houve maior consumo de nitrogênio, o que não foi verificado no presente trabalho. Quando esses pesquisadores calcularam o nitrogênio retido como porcentagem do $\mathrm{N}$ ingerido, novamente $\mathrm{o}$ tratamento com 2,0\% de uréia foi superior ao tratamento com $1,0 \%$, mas não foi diferente do tratamento com $1,5 \%$ de uréia. 


\section{CONCLUSÕES}

O consumo de matéria seca em dietas à base de cana-de-açúcar parece ser mais influenciado pelas fontes do que pelos teores de proteína. A suplementação da cana-de-açúcar com farelo de soja proporcionou maior ingestão de MS, MO, FDN, FDA, EB e ED em relação à suplementação com uréia, mesmo quando esta foi empregada para proporcionar teores de PB mais elevados do que o da dieta com farelo de soja.

A suplementação das dietas à base de cana com farelo de soja proporcionou maior digestibilidade da MS, MO, FDA, EB e maior retenção de $\mathrm{N}$ do que a suplementação com $1,0 \%$ de uréia sobre o peso da cana fresca, quando ambos suplementos foram utilizados para proporcionar iguais teores de PB. Quando comparado a suplementação com 1,5\% de uréia, a suplementação com farelo de soja não apresentou, no entanto, diferenças na digestibilidade aparente no trato total da MS, MO, FDN, FDA, EB e retenção de $\mathrm{N}$. Isso sugere que teores entre 14 a $16 \%$ de PB foram necessários para aumentar a digestibilidade e utilização do nitrogênio das dietas à base de cana-de-açúcar suplementadas exclusivamente com uréia. O uso de uréia na concentração de $2,0 \%$ não foi vantajoso por ocasionar maior perda de nitrogênio via urina, sem trazer benefícios na digestibilidade e ingestão de MS e demais frações das dietas, quando comparado às concentrações de 1,0 e $1,5 \%$. 


\section{REFERÊNCIAS BIBLIOGRÁFICAS}

ALLEN, M. S. Phisical constraints on voluntary intake of forages by ruminants. Journal of Animal Science, v.74, n.12, p. 3063-3075, 1996.

ALLEN, M. S.; OBA, M. Fiber digestibility of forages: variation measurement, and effect on animal performance. In: CALIFORNIA ANIMAL NUTRITION CONFERENCE, Fresno, 1997. Fresno: ROCHE VITAMINS, 1997. p. 99-119.

ALVAREZ, F. J.; PRESTON, T. R. Studies on urea utilization in sugar cane diets: effect of level. Tropical Animal Production, v. 1, n. 3, p. 194-201, 1976.

ARAÚJO, G. G. L.; COELHO DA SILVA, J. F.; VALADARES FILHO, S. C.; LEÃO, M. I.; VALADARES, R. F. D.; ALMEIDA, G. A. P. Efeito da degradabilidade da proteína sobre o consumo e digestão da proteína bruta do extrato etéreo e balanço de nitrogênio de vacas lactantes. Revista da Sociedade Brasileira de Zootecnia, v. 23, n.2, p. 258-267, 1994.

AROEIRA, L. J. M.; SILVEIRA, M. I.; LIZIEIRE, R. S.; MATOS, L. L. Digestibilidade, balanço de nitrogênio e concentração de amônia no rúmen de novilhos mestiços alimentados com cana-de-açúcar e uréia mais farelos de arroz ou de algodão. Revista da Sociedade Brasileira de Zootecnia, v.22, n. 6, p. 893-901, 1993a.

AROEIRA, L. J. M.; SILVEIRA, M. I.; LIZIEIRE, R. S.; MATOS, L. L; FIGUEIRA, D. G. Degradabilidade no rúmen e taxa de passagem da cana-de-açúcar mais uréia, do farelo de algodão e do farelo de arroz em novilhos mestiços Europreu x Zebú. Revista da Sociedade Brasileira de Zootecnia, v. 22, n. 4 , p. 552-564, 1993 b. 
AROEIRA, L. J. M.; SAMPAIO, I. B. M.; FIGUEIRA, D. G.; LOPES, F. C. F.; RODRIGUEZ, N. M.; TORRES, M. P. Degradabilidade "in situ" dos nutrientes da cana-de-açúcar e do farelo de algodão em bovinos alimentados com farelo de algodão e cana-de-açúcar adicionada de três níveis de uréia. Arquivo Brasileiro de Medicina Veterinária e Zootecnia, v. 45, n. 2 , p. $221-233,1993$ c.

AROEIRA, L. J. M.; LOPES, F. C. F.; DAYRELL, M. S.; LIZIEIRE, R. S.; TORRES, M. P. Digestibilidade, degradabilidade e taxa de passagem da cana-de-açúcar mais uréia e do farelo de algodão em vacas mestiças Holandês x Zebu em lactação. Revista da Sociedade Brasileira de Zootecnia, v. 24, n. 6, p. 1016-1026, 1995.

ASSOCIATION OF OFFICIAL ANALYTICAL CHEMISTS. Oficial methods of analysis. 15. ed. Washington, 1985. $1015 \mathrm{p}$.

BANDA, M.; VALDEZ, R.E. Effect of stage of maturity on nutritive value of sugar cane. Tropical Animal Production, v. 1, n. 2, p. 94-97, 1976.

BOIN, C. Efeitos desfavoráveis da utilização da uréia. In: SIMPÓSIO SOBRE NUTRIÇÃO DE BOVINOS, 2., Piracicaba, 1984. Uréia para ruminantes. Piracicaba: FEALQ, 1984. p. 25-79.

BOIN, C. Cana-de-açúcar na alimentação de ruminantes. In: D'ARCE, R. D.; BOIN, C.; MATTOS, W. R. S. (Ed.) Utilização de resíduos agroindustriais da cana-de-açúcar na alimentação de ruminantes. Piracicaba: FEALQ, 1985. p.19-52.

BOIN, C.; TEDESCHI, L. O. Cana-de-açúcar na alimentação de gado de corte. In: SIMPÓSIO SOBRE NUTRIÇÃO DE BOVINOS, 5., Piracicaba, 1993. Cana-de-açúcar e seus subprodutos para bovinos. Piracicaba: FEALQ, 1993. p. 107-126.

CLARK, J. H.; KLUSMEYER, T. H.; CAMERON, M. R. Microbial protein sintesis and flows of nitrogen fractions to the duodenum of dairy cows. Journal of Dairy Science, v. 75, n. 8, p. 2304-2323, 1992.

COX, D. R. Planning of experiments. New York: John Wiley, 1958. cap.10, p. 205-218: More about latin squares. 
DADO, R. G.; ALLEN, M. S. Intake limitations, feeding behavior, and rumen function of cows challenged with rumen fill from dietary fiber or inert bulk. Journal of Dairy Science, v. 78, n. 1, p. 118-123, 1995.

ELLIOTT, R.; FERREIRO, H. M.; PRIEGO, A. An estimate of the quatity of feed protein escaping degradation in the rumen of steers fed chopped sugar cane, molasses/urea supplemented with varying quantities of rice polishings. Tropical Animal Production, v. 3, n. 1, p. 36-39, 1978 a.

ELLIOTT, R.; FERREIRO, H. M.; PRIEGO, A.; PRESTON, T. R. Rice polishings as a supplement in sugar cane diets: the quantities of starch $(\propto-$ linked glucose polymers) entering the proximal duodenum. Tropical Animal Production, v. 3, n. 1, p. 30-35, 1978b.

FARIA, V. P de. O uso da cana-de-açúcar para bovinos no Brasil. In: SIMPÓSIO SOBRE NUTRIÇÃO DE BOVINOS, 5., Piracicaba, 1993. Canade-açúcar e seus subprodutos para bovinos. Piracicaba. FEALQ, 1993, p. 1-16.

FERREIRO, H. M.; PRESTON, T. R. Digestibility and voluntary intake of derinded sugar cane stalk with and without addition of cane tops. Tropical Animal Production, v. 2, n. 1, p. 90-99, 1977.

FERREIRO, H. M.; PRESTON, T. R.; SUTHERLAND, T. M. Digestibility of stalk and tops of mature and immature sugar cane. Tropical Animal Production, v. 2, n. 1 , p. 100-104, 1977a.

FERREIRO, H. M.; PRESTON, T. R.; SUTHERLAND, T. M. Investigation of dietary limitations on sugar cane based diets. Tropical Animal Production, v. 2, n. 1, p. $56-61,1977$ b.

FERREIRO, H. M.; SUTHERLAND, T. M.; PRESTON, T. R. Brix and dry matter content as indices of urea requirements in diets based on sugar cane. Tropical Animal Production, v. 2, n. 2, p. 213-218, 1977 c. 
FIGUEIRA, D. G.; AROEIRA, L. J. M.; RODRIGUEZ, N. M.; SAMPAIO, I. B. M.; LOPES, F. C. F.; TORRES, M. P. Dinâmica ruminal e pós ruminal da canade-açúcar e do farelo de algodão em bovinos alimentados com farelo de algodão e cana-de-açúcar suplementada com três diferentes níveis de uréia. Arquivo Brasileiro de Medicina Veterinária e Zootecnia, v.45, n.1, p.71-80, 1993.

FIGUEIREDO, M.P. Cana-de-açúcar e bagaço de cana tratado à pressão de vapor na dieta de ruminantes - efeitos sobre a fisiologia e microbiologia do rúmen. Piracicaba, 1990. 103p. Dissertação (Mestrado) - Escola Superior de Agricultura "Luiz de Queiroz", Universidade de São Paulo.

GOERING, N.K.; VAN SOEST, P.J. Forage fiber analysis: aparatus, reagents, procedures and some applications. Washington: USDA, 1970, 20p.

HOOVER, W. H. Chemical factors involved in ruminal fiber digestion. Journal of Dairy Science, v. 69, n. 10, p. 2755-2766, 1986.

HOOVER, W. H.; STOKES, S. R. Balancing carbohidrates and proteins for optimum rumen microbial yield. Journal of Dairy Science, v.74, n.10, p.3630-3644, 1991.

HUBER. J.T. Urea ao nível do rúmen. In: SIMPÓSIO SOBRE NUTRIÇÃO DE BOVINOS, 2., Piracicaba, 1984. Uréia para Ruminantes. Piracicaba: FEALQ, 1984. p. 6-24.

HUBER. J. T.; KUNG Jr, L. Protein and nonprotein nitrogen utilization in dairy cattle. Journal of Dairy Science, v. 64, n. 6, p. 1170-1195, 1981.

HUGUES-JONES, M.; ENCARNACIÓN, C.; DOME, F.; PRESTON, T.R. La influencia de forajes sobre los parametros de digstion en dietas basadas en caña de azucar. Tropical Animal Production, v. 6, n.3 , p. 306-311, 1981.

HUNTINGTON, G.B. Ruminant starch utilization progress has been extensive. Feedstuffs, p. 16-39, June 1994.

LAVEZZO, O.E.N. M.; LAVEZZO, W.; BURINI, R.C. Efeitos nutricionais da substituição parcial do farelo de soja por uréia, em dieta de ovinos. Comparação da digestibilidade aparente e balanço de nitrogênio com a cinética do metabolismo da ${ }^{15} \mathrm{~N}$-glicina. Revista da Sociedade Brasileira de Zootecnia, v. 25, n. 2, p. 282-297, 1996. 
LENG, R. A.; PRESTON, T. R. Sugar cane for cattle production: present constraints, perspectives and research priorites. Tropical Animal Production, v.1, n.1, p.1-26, 1976.

LUDOVICO, A. Avaliação de dietas à base de cana-de-açúcar (Saccharum officinarum L.) e diferentes niveis de semente de algodão (Gossypium hirsutum L.) Piracicaba,1993. 117p. Dissertação (Mestrado) - Escola Superior de Agricultura "Luiz de Queiroz", Universidade de São Paulo.

MEHREZ, A. Z.; ORSKOV, E. R.; McDONALD, I. Rates of rumen fermentation in relation to ammonia concentration. British Journal of Nutrition, v.38, p. $437-443,1977$

MERTENS, R. R. Predicting intake and digestibility using mathematical models of ruminal function. Journal of Animal Science, v. 64, p. 1548, 1987.

MONTPELLIER, F. A.; PRESTON, T. R. Digestibility of tops, rind, derinded stalk and the entire plant of sugar cane. Tropical Animal Production , v.2, n.1, p.13-17, 1977 a.

MONTPELLIER, F. A.; PRESTON, T. R Digestibility and voluntary intake on sugar cane diets : effects of chopping the cane stalk in particles of different sizes. Tropical Animal Production, v.2, n.1, p.40-43, 1977 b.

NATIONAL RESEARCH COUNCIL. Committe on Animal Nutrition. Nitrogen ruminat usage. Washington: National Academy of Science, 1985. 138p.

NATIONAL RESEARCH COUNCIL. Committe on Animal Nutrition. Nutrient requeriments of dairy cattle. 6. ed., Washington: National Academy of Science, 1989. 157p.

OLIVEIRA, J. S. Utilização de cana + uréia na recria de bovinos. Coronel Pacheco: Embrapa - CNPGL, 1985. 20 p. n.23. (Circular Técnica, 23).

OWENS, F. N.; GOETSCH, A. L. Digesta passage and microbial synthesis. In: MILLIGAN,L. P.; GROVUM,W. L.: DOBSON, A. Control of digestion and metabolism in ruminants. Canada : Reston Pub., 1986. cap11, p.196-223.

OWENS, F. N.; ZINN, R. Protein metabolism of ruminant animals. In: $\mathrm{CHURCH}, \mathrm{D}$.C. The ruminant animal: digestive physiology and nutrition. Portland: Prentice Hall, 1988. cap12, p.227-249. 
PATE, F. M. Nutritive value of sugar cane at different stages of maturity. Tropical Animal Production, v.2, n.1, p.108, dec 1977. Suplemment. IApresentado ao 2. Annual Meeting of Dominican Centre for Livestock Research with Sugar Cane, Santo Domingo, 1977 - Abstracts.I

PATE, F. M. Fresh chopped sugar cane in growing - finishing steer diets. Journal of Animal Science, v.53, n.4, p.881-888, 1981.

PEIXOTO, A. M. A cana- de açúcar como recurso forrageiro. In: CONGRESSO BRASILEIRO DE PASTAGENS, 8., Piracicaba, 1986. Anais. Piracicaba: FEALQ,1986. p.17-47.

PEREIRA, J. R. A.; ROSSI Jr., P. Manual prático de avaliação nutricional de alimentos. Piracicaba: FEALQ, 1994. 34p.

PRESTON, T. R. Nutritive value of sugar cane for ruminants. Tropical Animal Production, v.2, n.2, p.125-142, 1977.

PRESTON, T. R.; WILLIS, M. B. Intensive beef production. Oxford, U.K.: Pergamon Press Ltda, 2.ed, 1974. 566p.

PRESTON, T. R.; LENG, R. A. La cana de azúcar como alimento para los bovinos. Parte II: Aplicación comercial y economía. Animal Review, Roma, v. 27, p.44-48, 1978.

PRESTON. T. R.; LENG, R. A. Utilization of tropical feeds by ruminants. In; THIVEND, R. Digestive phisiology and metabolism in ruminants Westport: AVI Publishing, 1980. cap.30, p.621-640.

PRESTON, T. R.; CARCANO, C.; ALVAREZ, F. J.; GutieRREZ, D. G. Rice polishings as a supplement in a sugar cane diet effect of level of rice polishings and of processing the sugar cane by derinding or chopping. Tropical Animal Production, v.1, n.3, p.150-162, 1976.

PRIEGO, A.; LOPEZ, J. M.; WILSON, A.; SUTHERLAND, T. M. Rumen adaptation to diets based on sugar cane. Tropical Animal Production, v.2, n.2, p.180-184, 1977. 
REYNOLDS, C. K.; HUNTINGTON, G. B.; TYRRELL, H. F.; REYNOLDS, P. J. Net portal- drained visceral and hepatic metabolism of glucose, I- lactate, and nitrogenous compounds in lactating Holstein Cows. Journal of Dairy Science, v.71, p.1803-1812, 1988.

RODRIGUEZ, N. M.; FIGUEIRA, D. G.; AROEIRA, L. J. M.; TORRES, M. P.; LOPES, F. C. F. Efeito do nivel de uréia sobre a digestibilidade aparente e o balanço de nitrogênio em bovinos alimentados com cana-de-açúcar e farelo de algodão. Arquivo Brasileiro de Medicina Veterinária e Zootecnia, v.45,n.1, p.59-70, 1993.

RUSSEL, J. B.; Ó CONNOR, J. D.; FOX, D. G.; VAN SOEST, P. J.; SNIFFEN, C. J. A net carbohydrate and protein system for evaluating cattle diets: 1. Ruminal fermentation. Journal of Animal Science, v.70, p.35513561,1992 .

SANTOS, F. A. P. Conceitos atuais de nutrição protéica. In: SIMPÓSIO SOBRE PRODUÇÃO ANIMAL, 9., Piracicaba, 1997. Confinamento de bovinos: Anais. Piracicaba: FEALQ, 1997. p. 51-67.

SATTER, L. D.; SLYTER, L. L. Effect of ammonia concentration on rumen microbial protein production in vitro. British Journal of Nutrition, v.32, n.2, p.199-208, 1974.

SILVA, S. C. A cana-de-açúcar como alimento volumoso suplementar. In: SANTOS, F. A. P.; NUSSIO, L. G.; SILVA, S. C. Volumosos para bovinos. Piracicaba: FEALQ, 1993. cap. 4, p.59-74.

SILVESTRE. R.; MACLEOD, N.A.; PRESTON, T.R. Supplementation of sugar cane/ urea for growing cattle: levels of maize grain and a protein concentrate. Tropical Animal Production, v.1, n.3, p.206-214, 1976.

SIMAS, J. M. C. Processamento de grãos para rações de vacas leiteiras. In: SIMPÓSIO SOBRE PRODUÇÃOO ANIMAL, 9., Piracicaba, 1997. Confinamento de bovinos: Anais. Piracicaba: FEALQ, 1997. p.7-32.

SNIFFEN, C.J.; ROBINSON, P.H. Microbial growth and flow as influenced by dietary manipulations. Journal of Dairy Science, v.70, p. 425-441, 1987.

THEURER, C.B. Starch digestion: understanding and potential for improvement-introduction. Journal of Nutrition, v.122, p.170-171, 1992. 
VALDEZ, R. E.; ALVAREZ, F. J.; FERREIRO, H. M.; GUERRA, F.; LOPEZ, J.; PRIEGO, A.; BLACKBURN, T. H.; LENG, R. A. PRESTON, T.R. Rumen function in cattle given sugar cane. Tropical Animal Production, v.2, n.3, p.260-72, 1977.

VAN SOEST, P. J. Nutritional ecology of the ruminants. 2.ed. Ithaca: Comstock Publ; 1994. 476 p. 